\title{
Measles and Misrepresentation in Minnesota: Can There Be Liability for Anti-Vaccine Misinformation That Causes Bodily Harm?
}

\author{
DORIT RUBINSTEIN REISS* \\ JOHN DIAMOND**†
}

\section{TABLE OF CONTENTS}

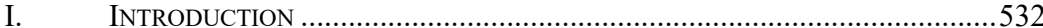

II. Negligent MisRePRESEnTAtion Risking PHYSICAL HARM ......................5.534

A. Duty of Care and Misrepresentation............................................535

B. $\quad$ The First Amendment and Misrepresentation .................................539

C. Negligent Misrepresentation......................................................541

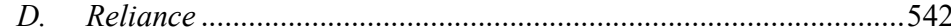

III. A Case StUdy: The Minnesota OUtBREAK ........................................54

A. Anti-Vaccine Efforts in Minnesota ...............................................548

IV. MEASLES, MMR, AND MisREPRESENTATION INVOLVING RISK OF

PHYSICAL HARM...............................................................................55

A. $\quad$ Liability to Third Parties ..................................................................55

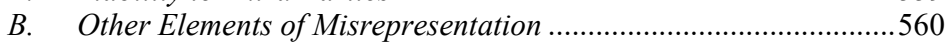

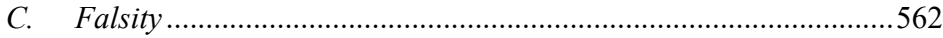

* (C) 2019 Dorit Rubinstein Reiss. Professor of Law, James Edgar Hervey Chair in Litigation, University of California, Hastings College of the Law.

** (C) 2019 John Diamond. The Honorable Raymond L. Sullivan Professor of Law, University of California, Hastings College of the Law. B.A., Yale College; Dip. Crim., Emmanuel College, Cambridge University; J.D. Columbia Law School.

$\dagger \quad$ We are grateful to Lynn Bahta, Karen Ernst, Joe Kurkland, Shauna Marshall, Paul Offit, Patricia Segal Freeman, and Patsy Stinchfield for invaluable comments to earlier drafts, and to Claire Baugher and Neema Monfared for wonderful research assistance. All errors are, of course, our own. 


\section{INTRODUCTION}

In 2017, a measles outbreak started in the Somali community in Minnesota and began spreading. ${ }^{1}$ The outbreak was directly linked to low rates of vaccination against measles in the community, brought about by antivaccine activists convincing the community that the measles, mumps, and rubella vaccine (MMR) causes autism. ${ }^{2}$ At the time these activists promoted that claim, studies in three continents spanning millions of children had found no link between the MMR and autism. ${ }^{3}$ These studies did not stop anti-vaccine activists from courting the Somali community and working to convince them such a link existed. Vaccination rates in the community dropped from over $90 \%$ in 2004 to close to $40 \%$ in $2014 .{ }^{4}$ The outbreak affected mostly - though not only - unvaccinated young children in the community, twenty-one of whom were hospitalized..$^{5}$ In addition to direct effects on the community, the outbreak cost the public health authorities over one million dollars. ${ }^{6}$

This outbreak raises the question of the possibility of a tort remedy available to those harmed by the incorrect claim that MMR causes autism. This Article uses the Minnesota outbreak as a springboard to examine if people physically harmed by anti-vaccine misinformation can use the tort of negligent misrepresentation to sue for compensation. ${ }^{7}$ It concludes that in some circumstances, where there is a consultation-like relationship, such a

1. Victoria Hall et al., Measles Outbreak-Minnesota April-May 2017, 66 MORBIDITY \& MORTALITY WKLY. ReP. 713, 713 (2017), https://www.cdc.gov/mmwr/volumes/66/wr/ pdfs/mm6627a1.pdf [https://perma.cc/G593-TQ3C].

2. $\quad$ Lena H. Sun, Anti-Vaccine Activists Spark U.S. State's Worst Measles Outbreak in Decades, INDEPENDENT (May 5, 2017, 9:21 PM), https://www.independent.co.uk/news/ world/americas/anti-vaccine-measles-outbreak-worst-in-decades-america-minnesotasomali-a7720976.html [https://perma.cc/ZAS8-5KJH].

3. Paul A. Offit, Bad Advice: Or Why Celebrities, Politicians, ANd Activists Aren't Your Best SOURCE OF HeALth Information 201 (2018).

4. Sun, supra note 2 .

5. Annual Summary of Communicable Diseases Reported to the Minnesota Department of Health 2017, Disease ConTrol Newsl. (Minn. Dep't of Health, St. Paul, Minn.), 2018, at 14, https://www.health.state.mn.us/diseases/reportable/dcn/sum17/2017 den.pdf [https://perma.cc/F4BA-BC2F].

6. Email from Cynthia Kenyon, Epidemiologist Supervisor, Minn. Dep't of Health, to Dorit R. Reiss, Professor of Law, U.C. Hastings Coll. of the Law (Apr. 4, 2018, 1:46 PM) (on file with authors).

7. See Restatement (SECOND) OF TorTs $§ \S 310-11$ (Am. LAw InSt. 1965). 
suit is possible. However, a suit is likely unsuccessful when the information is only shared online or on forums aimed at the general public.

The Minnesota outbreak is not, and will not be, the only case in which anti-vaccine misrepresentations directly contribute to harm. The end of 2018 and the start of 2019 are marked by outbreaks of measles in New York, Washington state, and other areas. ${ }^{8}$ Anti-vaccine groups mobilized to continue efforts to convince parents not to vaccinate, even in the midst of the outbreak, in both states. ${ }^{9}$ Other areas where anti-vaccine misinformation led to decreased immunization rates are also "hotspots" vulnerable to outbreaks. ${ }^{10}$ Even the specific situation in which the tort is examined in this Article has ongoing practical importance until other efforts improve immunization rates.

More generally, the Article highlights the challenges of using the tort when publicly shared misinformation causes physical harm. It offers thoughts on the limits of the tort and recommends how courts should deal with such a claim. It also advocates for states adopting the tort in narrow circumstances.

The Article consists of four parts. Part II introduces the tort of negligent misrepresentation causing physical harm and explains the elements courts focus on when analyzing these claims. Part III provides a detailed description of the Minnesota outbreak and the role anti-vaccine activists had in the outbreak. Part IV discusses whether different parties involved in the Minnesota outbreak would have a remedy under the tort of negligent misrepresentation and suggests that at least some of the actors would have a valid claim against the anti-vaccine activists. It also briefly addresses the closely related torts of conscious misrepresentation and economic misrepresentation as a

8. Troy Brown, Measles Outbreak Worst in Decades for Washington, New York, MEDSCAPE (Jan. 31, 2019), https://www.medscape.com/viewarticle/908466 [https://perma.cc/ JUT4-WKAL].

9. See, e.g., Tyler Pager, 'Monkey, Rat and Pig DNA': How Misinformation Is Driving the Measles Outbreak Among Ultra-Orthodox Jews, N.Y. Times (Apr. 9, 2019), https://www.nytimes.com/2019/04/09/nyregion/jews-measles-vaccination.html?smid= nytcore-ios-share [https://perma.cc/R63E-ULCX]; Measles?, INFORMED CHOICE WASH., https://www.informedchoicewa.org/measles/?fbclid=IwAR30ZmUIeaMyJyjZAYXprD5 HF20vyYaNDPTvow0osGwwhJfa_IGfQrsY708 [https://perma.cc/62Q6-EHSP].

10. See Jacqueline K. Olive et al., The State of the Antivaccine Movement in the United States: A Focused Examination of Nonmedical Exemptions in States and Counties, 15 PLOS MED., at e1002578 (June 12, 2018), https://journals.plos.org/plosmedicine/article? $\mathrm{id}=10.1371$ /journal.pmed.1002578 [https://perma.cc/V98W-X4GE] (explaining how hotspots in the United States - areas with low vaccination rates - are vulnerable to outbreaks). 
legal claim in this context. Part V addresses other circumstances, using other possible scenarios to explore the limits of the tort.

\section{NEGLIGENT MisRePRESENTATION RISKING PhySiCAL HARM}

The tort of negligent misrepresentation involving risk of physical harm, embodied in Section 311 of the Restatement (Second) of Torts, seemed directly applicable to situations like the outbreak. ${ }^{11}$ The courts use Section 311 in a variety of contexts; for example, courts hold employers liable for letters of recommendation that fail to warn other employers of a candidate's propensity for sexual abuse or violence. ${ }^{12}$ Does such a misrepresentation, however, translate to liability in circumstances including false healthcare information?

To prove a case of negligent misrepresentation that causes bodily harm, a plaintiff would have to show, at the least: (1) a negligent misrepresentation; (2) reasonable reliance on the information; and (3) reliance on the misrepresentation physically harmed the plaintiff or a foreseeable third party. ${ }^{13}$ Beyond the text of the Restatement, courts have read in two additional requirements. First, courts require a legal duty of care in order to

11. See Restatement (SECOnd) OF Torts $§ 311$ (Am. Law Inst. 1965).

(1) One who negligently gives false information to another is subject to liability for physical harm caused by action taken by the other in reasonable reliance upon such information, where such harm results

(a) to the other, or

(b) to such third persons as the actor should expect to be put in peril by the action taken.

(2) Such negligence may consist of failure to exercise reasonable care

(a) in ascertaining the accuracy of the information, or

(b) in the manner in which it is communicated.

Id. It is not quite clear yet how this will translate into the Restatement (Third) of Torts. The American Law Institute voted favorably on a proposal to have the Restatement (Third) address these torts. Press Release, Am. Law Inst., Four Restatement Projects Launch (Jan. 28, 2019), https://www.ali.org/news/articles/four-restatement-projects-launch/ [https://perma.cc/ BBE7-6ZZH]. While Restatement (Second) of Torts Section 310, Conscious Misrepresentation Involving Risk of Physical Harm, may also be applicable, our discussion of that tort will be short because of the difficulties in showing knowledge on the part of those making the misrepresentation. See infra Part V.

12. See, e.g., Gutzan v. Altair Airlines, Inc., 766 F.2d 135, 141 (3d Cir. 1985); Randi W. v. Muroc Joint Unified Sch. Dist., 929 P.2d 582, 584 (Cal. 1997). For a discussion and a criticism of the jurisprudence in this area, see Alissa J. Strong, "But He Told Me It Was Safe!": The Expanding Tort of Negligent Misrepresentation, 40 U. MEM. L. REV. 105, 120-30 (2009).

13. ReSTATEMENT (SECOND) OF TORTS $§ 311$ (AM. LAW InSt. 1965). 
impose liability. ${ }^{14}$ Second, the First Amendment imposes some, though not absolute, limits on the tort. ${ }^{15}$

Due to the importance of those limits, the following section opens with a detailed discussion of the duty and First Amendment restrictions. Afterwards, it addresses the elements of misrepresentation, negligence, and reliance.

\section{A. Duty of Care and Misrepresentation}

For a plaintiff to utilize Section 311, the courts require a finding that the defendant owed the plaintiff a duty of care. When a plaintiff relies on broad representations to the public, the courts do not, generally, find such a duty.

Although Section 311 itself does not mention a duty requirement, courts applying the tort consistently examine whether a legal duty exists. Before the Restatement, cases apparently limited the tort of misrepresentation to professionals giving information while engaged in their occupation or people presenting themselves as experts. ${ }^{16}$ The Restatement (Second), however, intentionally went beyond that, expressly applying liability to gratuitously given information and not requiring a professional context. Notwithstanding, both aspects may affect the reasonableness of a plaintiff's reliance. ${ }^{17}$

While the tort no longer requires a professional context or representing oneself as an expert, duty still applies. In the context of gratuitous healthcare information, courts appear concerned about excessive liability beyond what is justified by negligent - rather than intentional - conduct. First Amendment considerations, elaborated upon in Section II.B, may also underlie the duty requirement. Furthermore, the duty required appears to be more restrictive than just the act of misrepresentation, despite Restatement (Third) of Torts Section 37 imposing such a broad duty on actors. ${ }^{18}$ Some cases explicitly address duty, finding it is the determining factor. For example, in Connelly v. State, a mariner called the State Department of Water Resources to inquire about rising river levels and claimed his

14. See, e.g., Gourdine v. Crews, 955 A.2d 769 (Md. 2008).

15. Smith v. Linn, 48 Pa. D. \& C.3d 339 (C.P. Montgomery Cty. 1988), aff'd, 563

A.2d 123 (Pa. Super. Ct. 1989), aff'd, 587 A.2d 309 (Pa. 1991).

16. Strong, supra note 12, at 113-14.

17. See id. at 109, 149; see also Restatement (SECOND) Of TORTS $\S 311 \mathrm{cmt}$. c (AM. LAW INST. 1965).

18. See ReStATEMENT (ThIRD) OF TORTS $\S 37$ (AM. LAw InSt. 2012). 
property was damaged by reliance on negligent misrepresentations of the Department. ${ }^{19}$ The court rejected the Department's claim that their general duty to the public does not apply to the individual plaintiff here. ${ }^{20}$ The plaintiff set himself apart from the public by alleging he called the Department specifically, identified himself as a mariner owning property on the river in question, and inquired about a potential rise in water requiring him to secure his property. ${ }^{21}$ Therefore, the court held the plaintiff "[had] pleaded facts which take him out of the realm of an amorphous public receiving general information, and placed himself in the position of a businessman by identifying himself as such and making personal inquiry and relying upon the information given him." 22

Similarly, in White v. Kennedy Krieger Institute, Inc., a court found a clear duty based on the specific relationship between the plaintiff and researchers counseling the mother and the family. ${ }^{23}$ The Supreme Court of California determined, in the employment context, that an employer providing a letter of recommendation to a school can be sued for negligent misrepresentation because, applying the factors in Rowland v. Christian, ${ }^{24}$ the reliance and the result was imminently foreseeable. ${ }^{25}$ In another case, Bixby v. KBR, Inc., the court examined duty by applying a two-step analysis borrowed from Oregon's courts. ${ }^{26}$ The Bixby court used the two-step analysis in the context of negligent misrepresentation, too: "[f]irst, courts analyze whether there existed a special relationship between the parties due to a 'status, a relationship, or a particular standard of conduct that creates, defines, or limits the defendant's duty.", 27 In the alternative, "[w]here no such special relationship exists, courts proceed to the second step, analyzing the defendant's duty under general foreseeability principles, with the key inquiry being whether defendant 'unreasonably created a foreseeable risk

\footnotetext{
19. Connelly v. State of California, 84 Cal. Rptr. 257, 258-59 (Ct. App. 1970).

20. Id. at 259 .

21. Id. at 261-62.

22. Id. at 260 .

23. White v. Kennedy Krieger Inst., Inc., 110 A.3d 724, 748 (Md. Ct. Spec. App.

24. 443 P.2d 561, 564 (Cal. 1968).

25. Randi W. v. Muroc Joint Unified Sch. Dist., 929 P.2d 582, 588-91 (Cal. 1997). For criticism of this decision and others like it, see Strong, supra note 12, at 120-30.

26. 893 F. Supp. 2d 1067, 1089 (D. Or. 2012). In that case, the issue was alleged misrepresentation related to exposure to toxic substances. Id. at 1070. Bixby was eventually overturned on appeal for lack of personal jurisdiction, and its analysis is used here as persuasive materials only. Bixby v. KBR, Inc., 603 Fed. App'x. 605, 606 (9th Cir. 2015) (mem.). Importantly, at no point in the proceedings did any of the reviewing courts overturn the duty analysis. See id.

27. Bixby, 893 F. Supp. 2d at 1089 (quoting Buchler v. State, 853 P.2d 798, 800 (Or.
} 2015). 1993)). 
to a protected interest of the kind of harm that befell the plaintiff.",28 Because plaintiff - a member of the Oregon National Guard who developed hexavalent chromium poisoning as a result of exposure to sodium dichromate contamination while stationed at an Iraqi water plant - claimed a special relationship based on a contract and the safety regulations included in it, the court found plaintiff satisfied the first prong. ${ }^{29}$

More controversially, in Conte v. Wyeth, Inc., California's Supreme Court found that a drug manufacturer has a duty of care to users of the generic version of the drug. ${ }^{30}$ The court applied Section 311 to a plaintiff who was allegedly harmed by misrepresentations in the labeling of the brand name product. ${ }^{31}$ The Conte court, too, focused on whether there was a legal duty, and though it took an expansive view, it extended a wellestablished duty of manufacturers to provide warnings and did not create a new duty. ${ }^{32}$ Nevertheless, it was a dramatic expansion, and Conte's doctrine is still a minority doctrine that is heavily criticized from several directions. ${ }^{33}$

In other cases, the lack of a legal duty was fatal to plaintiffs' Section 311 claims. For example, in Bailey v. Huggins Diagnostic \& Rehabilitation Center, Inc., the court found no duty between a dentist who had made claims about the dangers of amalgams on both television and in several publications and a patient relying on such representations to replace her amalgams with an inferior substance. ${ }^{34}$ First, there was no duty because the dentist did not actually treat the plaintiff, and the plaintiff merely relied on the dentist's warnings. ${ }^{35}$ Second, the court held a duty did not exist based both on the lack of foreseeability of the harm and on the social utility of allowing authors to express themselves on public issues. ${ }^{36}$ The

28. Id. (quoting Fazzolari v. Portland Sch. Dist. No. 1J, 734 P.2d 1326, 1336 (Or. 1987)).

29. Id. at $1070,1089,1091$.

30. Conte v. Wyeth, Inc., 85 Cal. Rptr. 3d 299, 314-15 (Ct. App. 2008).

31. Id. at 311-13.

32. Id. at 318 .

33. See, e.g., Frank Scaglione, Comment, Resolving Drug Manufacturer Liability for Generic Drug Warning Label Defects, 47 ST. MARY's L.J. 219, 227-31 (2015).

34. Bailey v. Huggins Diagnostic \& Rehab. Ctr., Inc., 952 P.2d 768, 772 (Colo. App. 1997).

35. Id.

36. Id. at $772-73$. 
court's hesitation in applying such a duty to publishers is also found in Birmingham v. Fodor's Travel Publications, Inc. ${ }^{37}$

In Davis v. Mangelsdorf, a court held a doctor owed no duty to a third party harmed by an accident caused by a former patient. ${ }^{38}$ Similarly, a court found no duty on the part of a manufacturer to a third party after plaintiff alleged they misrepresented facts by omission to a patient taking their product. ${ }^{39}$ In that case, the plaintiff's husband died after a driver, suffering side effects from the manufacturer's drug, allegedly crashed into the husband. ${ }^{40}$ It should be noted that in both previous cases, the line between misrepresentation and failure to warn is somewhat blurry, and the question of duty is examined under a Tarasoff analysis of failure to warn. ${ }^{41}$ Tarasoff is certainly a reasonable test in determining duty when the misrepresentation consists of omissions in a situation where it applies -but its scope is unclear. ${ }^{42}$

Even where courts do not expressly address duty, successful cases using Section 311 involve a relationship that could conceivably create a duty of care between the parties. ${ }^{43}$ For example, in Guidry v. United States Tobacco Co., plaintiff sued tobacco manufacturers' trade associations; as

37. 833 P.2d. 70, 73-75 (Haw. 1992) (finding publisher of travel guide, which neither authored nor expressly guaranteed the contents of its publication, had no duty to warn the reading public of the contents of its publication); see also Alm v. Van Nostrand Reinhold Co., 480 N.E.2d 1263, 1266-67 (Ill. App. Ct. 1985) (refusing to apply the rule of negligent misrepresentation against a publisher of a how to book where the publisher made no specific endorsement of the book but merely published another's work).

38. Davis v. Mangelsdorf, 673 P.2d 951, 954-55 (Ariz. Ct. App. 1983).

39. Gourdine v. Crews, 955 A.2d 769, 772-73 (Md. 2008).

40. Id.

41. Tarasoff v. Regents of the Univ. of Cal., 551 P.2d 334, 345 (Cal. 1976). In Tarasoff, the California Supreme Court held that a psychotherapist has a duty to take reasonable steps to warn an identifiable potential third party victim when the therapist should know the patient being treated poses serious physical risk to the third party. Id.

42. See Jeffrey W. Burnett, Comment, A Physician's Duty to Warn a Patient's Relatives of a Patient's Genetically Inheritable Disease, 36 Hous. L. Rev. 559, $564-67$ (1999); Robert N. Cohen, Note, Tarasoff v. Regents of the University of California: The Duty to Warn: Common Law and Statutory Problems for California Psychotherapists, 14 CAL. W. L. REv. 153, 157-59 (1978); Robert B. Kaplan, Comment, Tarasoff v. Regents of the University of California: Psychotherapists, Policemen and the Duty to Warn-An Unreasonable Extension of the Common Law?, 6 GOLDEN GATE U. L. REV. 229, 240-43 (1975).

43. Traditionally, relationships of dependence, or where there is a special reason to expect action on the part of the defendant, can lead to a finding of a duty of care. Reflecting this, Sections 40-41 of the Restatement (Third) of Torts address such duty-creating special relationships with the plaintiffs, like innkeeper/guest, landlord/tenants, or custodian and those in custody, or the defendants, like parents with children or psychiatrist with patients. RESTATEMENT (THIRD) OF TORTS $\S \S 40-41$ (AM. LAW INST. 2012). Sections 42-43 address duty based on an undertaking to another. See Restatement (THIRD) OF TORTS $\S \S 42-43$ (AM. LAW INST. 2012). 
purchasers of tobacco products, the plaintiffs' more direct relationship was with the manufacturers of tobacco products, but the trade associations representing these manufacturers were directly involved in many relevant aspects, and hence, their duty easy to find. ${ }^{44}$ In Aana v. Pioneer Hi-Bred International Inc., plaintiffs were neighbors of the defendants, and the misrepresentation caused harm to their land-again, this was a specific, special, and defined relationship. ${ }^{45}$

In cases that do not fall into traditional duty categories, a state's approach to creating new duties would be relevant, and the legal situation would vary. States that follow the Restatement (Third) of Torts' broader approach to duty may impose broader liability under Section 311 . There may also be a reason, as addressed in Part IV, to find broader duty when culpability is high rather than when it is low, and to find broader duties towards less sophisticated recipients of information.

\section{B. The First Amendment and Misrepresentation}

Courts have consistently refused to hold publishers liable for misrepresentation when the materials they publish allegedly cause the physical harm. A leading case on this is Smith v. Linn. ${ }^{46}$ There, a woman died allegedly as a result of following the advice of a diet book the defendant published. ${ }^{47}$ The Court found that publishers are protected by the First Amendment when they publish on matters of public interest. ${ }^{48}$ Other jurisdictions have found similarly. ${ }^{49}$ The same approach has been applied to information provided to the public by media outlets. ${ }^{50}$ These courts focused on publishers' and outlets' liability rather than the author's, so there may be a question of whether the jurisprudence extends to creators of the content. There is at least an argument that creators of the content should not enjoy the same

44. Guidry v. U.S. Tobacco Co., 188 F.3d 619, 625-28 (5th Cir. 1999).

45. Aana v. Pioneer Hi-Bred Int'l, Inc., 965 F. Supp. 2d 1157, 1161-62 (D. Haw. 2013).

46. 563 A.2d 123 (Pa. Super. Ct. 1989), aff'd, 587 A.2d 309 (Pa. 1991).

47. Id. at 124

48. Id. at 126

49. See, e.g., Birmingham v. Fodor's Travel Publ'ns, Inc., 833 P.2d. 70, 75-76 (Haw. 1992); Alm v. Van Nostrand Reinhold Co., 480 N.E.2d 1263, 1266-67 (Ill. App. Ct. 1985).

50. See, e.g., Zamora v. Colum. Broad. Sys., 480 F. Supp. 199, 205-06 (S.D. Fla. 1979); Olivia N. v. Nat'l Broad. Co., 178 Cal. Rptr. 888, 892 (Ct. App. 1981); Bailey v. Huggins Diagnostic \& Rehab. Ctr., Inc., 952 P.2d 768, 772-73 (Colo. App. 1997); Walt Disney Prods., Inc. v. Shannon, 276 S.E.2d 580, 582-83 (Ga. 1981); DeFilippo v. Nat'l Broad. Co., 446 A.2d 1036, 1039-42 (R.I. 1982). 
protection: if the basis for the protection is concern that requiring publishers to fact check everything provided by a third party would interfere with economic activity, that does not apply similarly to the authors and creators of content. ${ }^{51} \mathrm{Alm}$, for example, emphasizes that free speech protections apply to publishers in relation to information provided to them by third parties, not to the creators of the information. ${ }^{52}$ Even if the rationale is not deterring the publishing of controversial information, ${ }^{53}$ it is not clear that the same extensive protection should apply to those who create the content. Nevertheless, there is a strong argument that some of the same concerns - that fear of litigation will lead creators of content to avoid publishing controversial materials, thus undermining vigorous debate on matters of public concern and the goals of the First Amendment - apply to authors.

The courts' reluctance to penalize creators of content aimed at the general public will lead to very careful application of Section 311. Courts impose First Amendment limits, for example, on intentional infliction of emotional distress claims not only when brought by public figures ostensibly trying to avoid the limits set on defamation suits ${ }^{54}$ but also when brought by a private individual for generalized speech that caused personal harm. ${ }^{55}$ In the context of misrepresentation in the vaccine context, too, some limits likely apply, but case law on this strongly suggests that they are not absolute. The limits are likely strongest in the context of information published to the general public, and less strong the closer and more individualized the relationship is between the information giver and the information receiver. In this, there is a connection between the application of the First Amendment and the requirement of a legal duty of care: the stronger the relationship creating the legal duty, the more parties can be required to take precautions to verify their speech and the weaker the protection from the First Amendment.

Even generalized information should not enjoy absolute protections. In an article from 1987, author John Diamond and his co-author James L. Primm proposed a distinction between three different kinds of potentially harmful media broadcasts and different treatments under the First Amendment. ${ }^{56}$ Diamond and Primm pointed out that full protection of media outlets, when speech causes harm, is in tension with other parts of our jurisprudence. ${ }^{57}$

51. See Smith, 563 A.2d at 125.

52. Alm, 480 N.E.2d at 1267.

53. See Smith, 563 A.2d at 124, 126

54. Hustler Magazine, Inc. v. Falwell, 485 U.S. 46, 50, 56 (1988).

55. Snyder v. Phelps, 562 U.S. 443, 457-58 (2011).

56. John L. Diamond \& James L. Primm, Rediscovering Traditional Tort Typologies to Determine Media Liability for Physical Injuries: From the Mickey Mouse Club to Hustler Magazine, 10 Hastings J. COMM. \& ENT. L. 969, 973 (1987).

57. Id. at $972-73$. 
To reconcile this, they suggested a three-category classification. ${ }^{58}$ In one such category, they argue there is no good reason to protect a media outlet, more than others engaged in similar conduct, when the outlet publishes instructions. ${ }^{59}$ In fact, at least some of the arguments for strict product liability - though not all - apply to this category: the publisher is better able to spread costs and liability would incentivize safe publishing. ${ }^{60}$ However, because defining the product of a publication is hard, strict liability is inappropriate. A negligence standard applied to instructional liability is appropriate because it balances the considerations for liability with the concerns of limiting speech. ${ }^{61}$ Similarly, media sponsored activities should be treated like similar activities sponsored by others-for example, a competition organized by a sports association. ${ }^{62}$ In contrast, simulated violence-showing how to do violent or dangerous things - should be protected unless there was intent to cause another harm. ${ }^{63}$ The rationale behind this limit is concern that letting the court assess the subjective value of speech can lead to its worthiness being judged on the basis of the majority's prejudices, going directly against the goals of the First Amendment. ${ }^{64}$

We believe this typology makes as much sense today as when the article was published and offers a principled way to impose liability on outlets providing generalized content in some contexts and not others, without overburdening the First Amendment. This typology can provide a guide in other cases, too: when liability for public speech is closely analogous to liability imposed for non-public speech, there is more justification for imposing it than if it is not.

\section{Negligent Misrepresentation}

To fulfill the elements of Section 311, a plaintiff must show that the defendant at least negligently presented the false information. ${ }^{65}$ In Aana

58. Id. at 972 .

59. Id. at $973,976-78$.

60. Id. at $977-78$.

61. Id. at $981-83$.

62. See, e.g., Weirum v. RKO Gen., Inc., 539 P.2d 36, 37-41 (Cal. 1975) (holding radio station liable for wrongful death when a teenage listener participating in the radio station's contest to first locate the radio disk jockey in a red car forced the victim off road).

63. Diamond \& Primm, supra note 56, at 993-94.

64. Id. at 933 .

65. Rodriguez v. Lab. Corp. of Am. Holdings, 13 F. Supp. 3d 121, 130 (D.D.C. 2014) (citing Hall v. Ford Enters., Ltd., 445 A.2d 610, 612 (D.C. 1982)). 
v. Pioneer Hi-Bred International, Inc., neighboring farmers falsely represented to the county that they would implement a conservation plan that would exempt the farmers from county oversight and deter owners of neighboring land from initially bringing legal actions against the farmers. ${ }^{66}$ In White v. Kennedy Krieger Institute, Inc., researchers wrongly assured plaintiff's mother, participating in a study of lead exposure, that her exposure was not dangerous. ${ }^{67}$ Note that these cases show that what is needed is actual, objective falsity of the data, not subjective disagreements on the risk/ benefit analysis.

For the purposes of Section 311, negligence is enough, so defendants do not have to know that the information is false but have to have been objectively unreasonable. ${ }^{68}$

\section{Reliance}

Two issues arise under reliance, aside from the need to show reliance. The first issue is the reasonableness of the reliance on defendant's representation. Second, to what degree is reliance fulfilled when the reliance is on representations made to a third party. For example, if one hears from their neighbor that MMR causes autism, and the neighbor heard that MMR causes autism from another source, is there a claim against the source instead of, or in addition to, the neighbor? In many of the cases, there was something about the situation that made reliance reasonable. For example, in Guidry v. United States Tobacco Co., the reliance on a trade associations information about the safety of a product, which can be expected to have come from the manufacturers, was reasonable. ${ }^{69}$ This was due to the manufacturers being the most direct and best-informed source of information about their product. $^{70}$ In Connelly, relying on researchers conducting the research was also reasonable. ${ }^{71}$

Most courts find that third parties can sue under Section 311 if: (1) the third party relied on the misrepresentation; (2) the misrepresentation was communicated to the third party; and (3) the communication and reliance was foreseeable by the defendant. ${ }^{72}$

66. 965 F. Supp. 2d 1157, 1165 (D. Haw. 2013).

67. 110 A.3d 724, 748 (Md. Ct. Spec. App. 2015).

68. See Connelly v. State, 84 Cal. Rptr. 257, 269-70 (Ct. App. 1970); Restatement (SECOND) OF TORTS $\S 311$ (AM. LAW INST. 1965).

69. 188 F.3d 619, 626-27 (5th Cir. 1999).

70. See id.

71. See Connelly, 84 Cal. Rptr. at 262.

72. See, e.g., Jowers v. BOC Grp., Inc., No. 1:08-CV-0036, 2009 WL 995613, at *8 (S.D. Miss. Apr. 14, 2009) (quoting Clark v. St. Dominic-Jackson Mem'l Hosp. 660 So.2d 970, 974 (Miss. 1995)), aff'd in part, vacated in part, remanded sub nom. Jowers v. Lincoln Elec. Co., 617 F.3d 346 (5th Cir. 2010). 
Demonstrating these elements is Jowers v. BOC Group, Inc. ${ }^{73}$ There, plaintiff was a shipyard worker who sued the manufacturers of a welding rod for injuries after he inhaled welding fumes at work. ${ }^{74} \mathrm{He}$ admitted to never having read any of the materials provided by the manufacturer for the rod but asserted that his employer had. ${ }^{75}$ Furthermore, he claimed that his employer relied on the manufacturer's representation-or lack thereof - that the rod was not hazardous, and his employer then passed on this information to plaintiff. ${ }^{76}$ In denying the defendant's motion for summary judgment, the court found evidentiary basis from the plaintiff's assertion:

[Plaintiff] asserts the defendants purposefully gave false information regarding welding fume safety to [his employer] (knowing the information would be passed on to [plaintiff]), the defendants knew or should have known this information would induce [plaintiff] to take insufficient protective measures when welding, [plaintiff] and other . . . welders actually relied on the false information provided by the defendants, and [plaintiff's] reliance and actions involved an unreasonable risk of physical harm. ${ }^{77}$

Based on these facts, the plaintiff successfully utilized Section 311's third party protection. $^{78}$

In Woods v. R.J. Reynolds Tobacco Co., however, the court did not extend Section 311's third party liability to plaintiff. ${ }^{79}$ There, plaintiff claimed she "neither heard nor read any statements by the defendants or any statements which could be attributed to the defendants" but that she relied on information the defendants had passed on to her physicians and her children regarding the safety of smoking. ${ }^{80}$ It was this representation, made to her children and physicians, that plaintiff relied on and this representation that she alleged harmed her. ${ }^{81}$ The court rejected this argument pointing out that plaintiff "never saw, heard, or relied on any statements made by any tobacco company," and, "regardless of who passed them on to her," her reliance on such statements was unreasonable. ${ }^{82}$ Instead, the court held that she relied solely on the

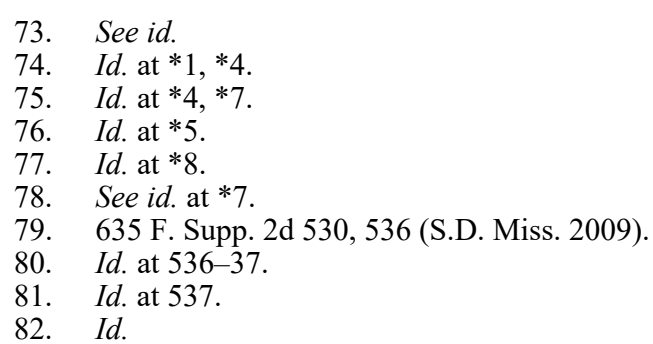


statements of her physicians and children, not the tobacco companies. ${ }^{83}$ It should be noted that the opinion's emphasis was on the fact that plaintiff did not rely on the statements of the tobacco company. This focus does not negate reliance on a third party's statements that are actually communicated to the third party.

One exception to the need of reliance on defendant's misrepresentation is that children can recover even if the reliance was by their parents, not themselves. ${ }^{84}$

Third party claims are particularly interesting in the context of infectious disease. Ponder this hypothetical: a person, relying on a misrepresentation that vaccines cause autism, infects another person. Does the infected person have a claim against the party that made the representation to the first person? This situation does not exactly mirror the case law on misrepresentation, but one can justify an exception. Infectious diseases, by their nature, transmit to others. Limiting the tort to those who directly spread the disease may not sufficiently compensate those harmed by the misrepresentation to not vaccinate. It has also been addressed in the different context of duty to third parties and is examined from that perspective in Part IV.

\section{A CASe Study: The Minnesota OUtbreaK}

Putting aside Section 311, this Section focuses on the Minnesota outbreak. We are using the 2017 Minnesota measles outbreak as a case study because it is an example where efforts were clearly made, based on incorrect information, to convince a specific population to act in a certain way. These representations, at least purportedly, led to physical harm. It seems fair to hold those convincing a targeted group of an incorrect fact liable for very foreseeable harms resulting from their efforts. Examining whether the tort, under our jurisprudence, applies to this context can help address related cases in future and also assess the weaknesses and limits of the jurisprudence in this area.

In the late 1990 s and early 2000 s, after a civil war ${ }^{85}$ accompanied by years of famine, drought, and floods, a surge of Somali refugees arrived

83. $I d$.

84. See Comm. on Children's Television, Inc. v. Gen. Foods Corp., 673 P.2d 660, 673-74 (Cal. 1983).

85. See Somalia Country Profile, BBC (Jan. 4, 2018), http://www.bbc.com/news/worldafrica-14094503 [https://perma.cc/3CRN-LABK].

Somalia collapsed into anarchy following the overthrow of the military regime of President Siad Barre in 1991. As rival warlords tore the country apart into clan-based fiefdoms, an internationally-backed unity government formed in 2000 struggled to establish control, and the two relatively peaceful northern regions of Somaliland and Puntland effectively broke away. The seizure of the capital Mogadishu and much of the country's south by a coalition of Islamist shariah 
in the United States. ${ }^{86}$ Out of about 106,000 Somalis that now live in the United States, approximately $40 \%$ live in Minnesota. ${ }^{87}$ Minnesota's Somali population makes up the second largest group of foreign-born Minnesotans, ${ }^{88}$ and Minnesota is home to the largest Somali community in the United States. ${ }^{89}$ Most of this community lives in metropolitan areas, particularly Minneapolis. $^{90}$

In 2008, researchers in Sweden published a report finding the prevalence of autism spectrum disorders in Somali children between seven to seventeen years old in Stockholm was about four times higher than the prevalence of autism in non-Somali children. ${ }^{91}$ Aggregate data from Minneapolis' school system showed that although Somalis only accounted for $6 \%$ of the city's public school population, they constituted $17 \%$ of early childhood

courts in 2006 prompted an intervention by Ethiopian, and later, African Union, forces. Since 2012, when a new internationally-backed government was installed, Somalia has been inching towards stability, but the new authorities still face Id.

a challenge from Al-Qaeda-aligned Al-Shabab insurgents.

86. Heather Linehan, Somali-Americans in Minnesota: Overview, MinN. Hist. CTR., http://libguides.mnhs.org/somali [https://perma.cc/978M-UMAR].

87. See U.S. CENSus BuREAU, B05006, 2017 AMERICAN COMMUNITy SuRVEY 1-YeAR

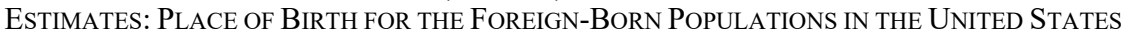
(2018).

88. Id. (estimating approximately 40,000 foreign-born Somalis lived in Minnesota in 2017).

89. U.S. CENSUS BuREAU, B04006, 2017 AMERICAN COMMUNITY SURVEY 1-YEAR ESTIMATES: PEOPLE REPORTING ANCESTRY (2018) (estimating approximately 69,500 people of Somalian ancestry lived in Minnesota in 2017); see also Kyle Almond, Somalis Finding Their Place in Minnesota, CNN, http://www.cnn.com/interactive/2017/02/us/somali-minnesotaphotos/ [https://perma.cc/Y24U-ARUU] (According to Arthur Nazaryan, a freelance photojournalist covering this topic, Minneapolis has the "biggest Somali community in North America, possibly in the world outside of East Africa.... It's like the cultural hub of the Somali diaspora ....").

90. U.S. CEnsus BuREau, B04006, 2013-2017 American COMMUnity Survey 5YeAr Estimates: PeOPle RePORTING ANCESTRy (2018). Karen Ernst, a Minnesota resident, pointed out that the neighborhood in question is structured so that the people live in very close proximity, creating conditions where transmission of disease is highly likely. Personal Communication from Karen Ernst to Dorit R. Reiss \& John L. Diamond, Professors of Law, U.C. Hastings Coll. of the Law (Dec. 5, 2018) (on file with authors).

91. Martina Barnevik-Olsson, Christopher Gillberg \& Elisabeth Fernell, Prevalence of Autism in Children Born to Somali Parents Living in Sweden: A Brief Report, 50 DEVELOPMENTAL Med. \& Child Neurology 598, 598 (2008). 
special education students identified as having autism. ${ }^{92}$ The Minnesota Department of Health, due to the impression of a disproportionate number of Somali-American Children diagnosed with autism, funded a study by the University of Minnesota to examine autism prevalence across population groups. ${ }^{93}$

The initial results put the rate of autism among Somali-American children at one in thirty-two, very close to the estimated one in thirty-six incidences of autism in Caucasian-American children. ${ }^{94}$ This was higher than the diagnosed rate of autism among non-Somali Black children and Hispanic children, which may reflect limits in the ability of the researchers to get accurate data about some populations. ${ }^{95}$ The study was also based on a very small sample size - "with data on just 255 children with autism out of more than 12,000 children within the schools overall." 96 It was estimated that "[o]f the total population, about 1,000 children are Somali and [thirtyone] of those children have autism." 97

Amy Hewitt, a disability researcher at the University of Minnesota's Institute on Community Integration in Minneapolis, and other researchers involved in the study reported in 2013 that one hundred percent of the SomaliAmerican children that have been diagnosed with autism in Minneapolis have an intellectual disability. ${ }^{98}$ These rates were much higher than in any other group; generally, while numbers range, intellectual disability is closer

92. Virginia Hughes, Scientists Probe Reports of Somali Autism 'Cluster,' SPECTRUM News (Sept. 17, 2008), https://spectrumnews.org/news/scientists-probe-reports-of-somaliautism-cluster/ [https://perma.cc/A4CX-829F].

93. See Emily Sohn, Why Autism Seems to Cluster in Some Immigrant Groups, ScI. AM. (Nov. 29, 2017), https://www.scientificamerican.com/article/why-autism-seems-to-clusterin-some-immigrant-groups/ [https://perma.cc/2WKK-9WCF].

94. Minneapolis Somali Autism Spectrum Disorder Prevalence Project, U. MINN., https://rtc.umn.edu/autism/ [https://perma.cc/FJ33-NXPT].

95. Id.

Even when doctors try to be culturally sensitive, many still get it wrong, adds [Katherine] Zuckerman, [a pediatrician at Oregon Health and Science University in Portland]. In a 2013 study of 267 pediatricians in California, she and her colleagues found that less than one-third offered screening for autism in Spanish as recommended by the American Academy of Pediatrics. Only 10[\%] offered both Spanish-language autism screening and general developmental screening. The researchers found that doctors had a tougher time assessing autism in Latino children from Spanish- speaking families - and it seems their discomfort makes them more likely to look the other way. "If providers feel uncomfortable about it, they're more likely to do nothing," Zuckerman says. "And then diagnosis gets delayed or it just never happens."

Sohn, supra note 93.

96. Sohn, supra note 93.

97. Id.

98. Id. 
to one-third of all diagnoses of autism. ${ }^{99}$ This may well reflect the fact that autism may go undiagnosed in Somali children who have lower support needs, dismissed as cultural differences. ${ }^{100}$

Addressing the study generally, the Scientific American pointed out:

For any family, navigating an autism diagnosis is a long process full of paperwork, questions and decisions. When those conversations happen in a foreign language within an unfamiliar healthcare and educational system, the confusion can escalate - especially among people from cultures ... that stigmatize mental illness or have no concept of autism at all.

...

The 2012 study of Swedish children hints at another possible influence: Among children born to immigrants, autism with intellectual disability is most prevalent among children born within about a year after their mothers moved. This finding suggests that the risk is tied specifically to relocating during pregnancy, says Dheeraj Rai, a psychiatrist at the University of Bristol in the U.K. "This makes us question whether it's just ethnicity," Rai says, "or if there's a role for migration and, particularly, stressful migration."

The first and only large-scale attempt to dig into the link between migration and autism in the [United States] also implicates a role for maternal stress in autism. That 2014 study was based on data from more than 1.6 million children born in Los Angeles County between 1995 and 2006. It found that children born to women from current or former war zones might be particularly vulnerable to autism. ${ }^{101}$

The nuances and limits, however, were lost in the news coverage of the study. What the parents in the Somali community heard was that the rate of autism, and especially autism accompanied by intellectual disability, was abnormally high in their community. ${ }^{102}$ They were convinced this would never happen "at home" and searched for answers for why it was happening in Minnesota. ${ }^{103}$ These parents were even more vulnerable to offered support because of the stigma attached to mental illness generally, and autism

99. Deborah L. Christensen et al., Prevalence and Characteristics of Autism Spectrum Disorder Among Children Aged 8 Years-Autism and Developmental Disabilities Monitoring Network, 11 Sites, United States, 2012, 65 SurveIllance Summaries, Apr. 1, 2016, at 1, 7, https://www.cdc.gov/mmwr/volumes/65/ss/pdfs/ss6513a1-H.pdf [https://perma.cc/9AWQE5AF].

100. Sohn, supra note 93.

101. Id.

102. See id.

103. See id.; see also Shanna Miller-Gairy \& Saul Mofya, Culture, Tradition, Autism Spectrum Disorder and Somali Refugee Mothers, in ENVIRONMENT AND Public HeAlth: Environmental Health, Law and International Perspectives 137, 140 (I. Leslie Rubin \& Joav Merrick eds., 2015). 
specifically, in the Somali community. ${ }^{104}$ Traditionally, problems were handled within the family, with an emphasis on prevention-when, as here, that was not possible, stigma was attached. ${ }^{105}$

\section{A. Anti-Vaccine Efforts in Minnesota}

At least as early as 2008, anti-vaccine activists focused on the Somali community in Minnesota. In November 2008, the anti-vaccine blog Age of Autism, which promotes the view that vaccines cause autism, ran several articles describing the situation in the Somali community in Minnesota, emphasizing an alleged link between vaccines and autism. ${ }^{106}$ On November 19, 2008, J.B. Handley, co-founder of Generation Rescue — an organization dedicated to claiming vaccines cause autism and promoting untested cures like chelation for autism - penned An Open Letter to the Somali Parents of Minnesota in which he said:

Somali parents, I offer this advice as the father of a son with autism. Like many of you, I watched my normal son descend into autism after receiving his vaccines. I genuinely believe too many vaccines given too soon in our children's lives is the primary trigger for the autism epidemic. Just to clarify: I'm not a doctor, I'm not giving you medical advice, I'm giving you my opinion.

I also want to tell you something that I think many of you have already realized: you cannot trust the Minnesota Department of Health to do the right thing. They may help you find educational services for affected children, and that's a very good thing, but they will do nothing to help reduce the number of Somali children with autism in the future nor help the ones with autism recover and resume normal functioning.

104. See Deborah L. Scuglik et al., Mayo Clinic Coll. of Med., When the Poetry No Longer Rhymes: Mental Health Issues Among Somali Immigrants in the USA, 44 TRANSCULTURAL PSYCHIATRY 581, 587 (2007) (stating that generally, the community rallies around members with mental health issues, but there is a culture of silence that may prevent seeking help, and a stigma for those labeled as suffering from mental disorders); Kim Bellware, Doctors Weren 't Listening to Somali Immigrants' Autism Concerns. Then Anti-Vaxxers Did., HuFF POST (May 11, 2017, 5:46 AM), https://www.huffingtonpost.com/entry/minnesota-measlesoutbreak_us_591224dfe4b05e1ca202a154 [https://perma.cc/5CNY-FJYD] (“'It's a stigma, like, "What have you done in the past for your child to have this?"' [Deeqa] Husseun[, vice president of the Somali Parents Autism Network] said.").

105. Scuglik et al., supra note 104, at 586-87.

106. See, e.g., Anne Dachel, On Autism, Somalis Feel the Chill in Minnesota, AGE Autism (Nov. 20, 2008, 5:55 AM), http://www.ageofautism.com/2008/11/on-autism-somal. html [https://perma.cc/MC6F-E7BE]; Nancy Hokkanen, Autism Strikes 1 in 28 Somali Children in Minnesota, Age AutiSM (Nov. 18, 2008, 5:20 AM), http://www.ageofautism.com/2008/ 11/by-nancy-hokkan.html [https://perma.cc/UU4Z-3QF3]; David Kirby, Minnesota and the CDC Confer on Somali Autism Situation: CDC's Office of the Director: Autism May Result from "Chemical Exposures," AGE Autism (Nov. 24, 2008, 9:50 PM), http://www.ageo fautism.com/2008/11/minnesota-and-t.html [https:/perma.cc/79B4-UXH2]. 
You see, the Minnesota Department of Health is nothing more than a puppet for the Centers for Disease Control, and they will never lead the way in addressing the vaccine issue. I'm personally embarrassed for our country to see the behavior of these people, but they are simply acting out many universal human traits of denial, corruption, and self-protection. 107

Among the other advice Mr. Handley gave the parents was: "For MMR vaccine, consider not giving to boys. At the least, delay the shot until a child is [two], and try very hard to break the shot up into three shots."108

Other articles from 2008 also show how closely involved anti-vaccine activists outside the Somali community were watching the community and working to convince it of the link between vaccines and autism. ${ }^{109}$

In 2009, Mr. Handley financed flights of members of the Somali community to attend Autism One, a conference devoted to promoting alternative, untested treatments for autism. ${ }^{110}$ Many of these treatments are based on the view that vaccines cause autism. ${ }^{111}$ In describing his experience of the conference, one father described how the conference solidified his beliefs, among other things, that "irresponsible vaccine administration can and did injure our kids." 12 Influenced by this conference, the father said that he and the other participants "will seek out all mothers of newborn babies and all new couples in order to educate them on potential hazards and what their rights are." 113

107. J.B. Handley, An Open Letter to the Somali Parents of Minnesota, AGE AutiSM (Nov. 19, 2008, 5:55 AM), http://www.ageofautism.com/2008/11/an-open-letter.html [https:// perma.cc/84KM-5PN6].

108. Id.

109. See, e.g., Mark F. Blaxill, Out of Africa and Into Autism: More Evidence Illuminates the Somali Anomaly in Minnesota, AGE AUTISM (Nov. 24, 2008, 9:13 PM), http://www. ageofautism.com/2008/11/out-of-africa-a.html [https://perma.cc/9YSL-9XUX]; Patti Carroll, MN Department of Public Health Coerces Somali Families Into MMR Vaccine, AGE AuTiSM (June 8, 2016, 5:59 PM), http://www.ageofautism.com/2016/06/mn-departmentof-public-health-coerces-somali-families-into-mmr-vaccine.html [https://perma.cc/FY6J5TFY]; Dachel, supra note 106; David Kirby, Somali Gloves Come Off: Autism in Minnesota, Age Autism (Nov. 18, 2008, 2:52 PM), http://www.ageofautism.com/2008/11/somaligloves-c.html [https://perma.cc/573V-RZFY]; David Kirby, Somali Parents Give the Autism Forum a "C+," AGE Autism (Nov. 17, 2008, 4:00 PM), http://www.ageofautism.com/ 2008/11/somali-parents.html [https://perma.cc/2ECT-MV5X].

110. Abdulkadir Khalif, Autism One 2009-What Somali Immigrants from Minnesota Learned, AGE AuTISM (June 23, 2009, 5:45 AM), http://www.ageofautism.com/2009/06/autismone-2009-what-somali-immigrants-from-minnesota-learned.html [https://perma.cc/JA6Y-PT8X].

111. See id.

112. Id.

113. Id. 
This experience draws a direct link between efforts of the anti-vaccine activists persuading Somali parents into believing that vaccines cause autism and the increasing belief in the connection between vaccines and autism in that community.

In response to an article by Minnesota anti-vaccine activists claiming, again, that vaccines cause autism, a person identifying themselves as a Somali parent stated:

Thank you so much for this important information. Somali parents are so grateful to you and Laura for appearing on Somali TV and informing the community about vaccines and the damage done to our kids. ${ }^{114}$

Prior to 2008, over 90\% of Minnesota-born American-Somali children in Hennepin County the most populated county in Minnesota, which includes Minneapolis, received MMR. ${ }^{115}$ However, starting in 2008, the percentage of MMR among young Somali-American children born in the county declined dramatically. ${ }^{116}$ As suggested above, this decline can be fairly connected to the anti-vaccine efforts.

At this point, many large-scale studies from all around the world studied whether MMR causes autism. ${ }^{117}$ No link was found, and other studies strongly pointed to a genetic cause. ${ }^{118}$ Anti-vaccine activists keenly followed that literature and knew of these studies - even though they found reasons to dismiss that evidence. ${ }^{119}$

114. Hodan, Comment to Thimerosal and Autism Rates: A Minnesota Perspective, AGE Autism (July 7, 2009, 11:08 PM), http://www.ageofautism.com/2009/07/thimerosaland-autism-rates-a-minnesota-perspective.html [https://perma.cc/SKZ5-MRSY]. Hodan Hassan is a mother of a child with autism and has been outspoken in other forums. See, e.g., Lorna Benson, Somalis, Health Department at Odds Over Autism, Vaccines, CURRENT (May 10, 2011), https://www.thecurrent.org/feature/2011/05/10/somalis-autism [https://perma.cc/E769-37VD].

115. Hall et al., supra note 1, at 715 .

116. Id.

117. See, e.g., Jeffrey S. Gerber \& Paul A. Offit, Vaccines and Autism: A Tale of Shifting Hypotheses, 48 CLINICAL INFECTIOUS DisEASES 456, 456-58 (2009).

118. See Trent Gaugler et al., Most Genetic Risk for Autism Resides with Common Variation, 46 NATURE GENETICS 881, 884 (2014), http://dx.doi.org/10.1038/ng.3039 [https:// perma.cc/56GG-5HHA] (arguing that the narrow-sense heritability of autism's genetic architecture is approximately $52.4 \%$, with most due to common variation); Guillaume Huguet, Elodie Ey \& Thomas Bourgeron, The Genetic Landscape of Autism Spectrum Disorders, 14 AnN. Rev. GenOMICS \& HuM. GenETiCs 191, 191 (2013), https://www.researchgate.net/ publication/251233406_The_Genetic_Landscapes_of_Autism_Spectrum_Disorders [https:// perma.cc/JHK7-GX5Z] ("For the majority of individuals with ASD, the causes of the disorder remain unknown; however, in up to [25\%] of cases, a genetic cause can be identified."); Mark N. Ziats \& Owen M. Rennert, The Evolving Diagnostics and Genetic Landscapes of Autism Spectrum Disorder, FrONTIERS GENETICS (Apr. 26, 2016), https://www.frontiersin.org/ articles/10.3389/fgene.2016.00065/full [https://perma.cc/S63A-VU6V].

119. See generally FOURTEEN STUD., https://www.fourteenstudies.org [https://perma.cc/ MPD5-JT2B]. This site attempted to deconstruct many of the studies-clearly showing 
In 2011, Minnesota saw an outbreak of measles starting in the Somali community. ${ }^{120}$ The 2011 outbreak started with a thirty-month-old unvaccinated Somali child who acquired measles while visiting Kenya. ${ }^{121}$ The child spread the disease to a nine-month-old baby who was too young to be vaccinated. ${ }^{122}$ The outbreak totaled twenty-one cases in March and August, including seven babies too young to be vaccinated with MMR and seven children who were old enough to be vaccinated but were not because of parental concerns. ${ }^{123}$ Fourteen of the children, or sixty-seven percent, were hospitalized, and one of the children, too young to be immunized, was in critical care, near death, on a ventilator for fifteen days from Measles pneumonia; the child survived, although long-term consequences of measles are unknown. ${ }^{124}$

In a paper reviewing the outbreak, authors pointed to the role of antivaccine activists in promoting MMR fears among parents:

The MDH Immunization Program also began receiving reports from health care providers regarding MMR vaccine refusal in the same community owing to parental concerns that MMR vaccine causes autism. Reports described local anti-vaccine activists' impact on the community. In addition, Andrew Wakefield, the former

that anti-vaccine activists were aware of them. See id. The effort was criticized by science bloggers. See Mark Crislip, 14 Studies Later*, SCI.-BASED MED. (Apr. 24, 2009), https://science basedmedicine.org/14-studies-later/ [https://perma.cc/5W34-8MKV]; David Gorski, Welcome Back, My Friends, to the Show that Never Ends, Part II: Generation Rescue, the Anti-Vaccine Propaganda Machine, and "Fourteen Studies," SCI.-BASED MED. (Apr. 13, 2009), https:// sciencebasedmedicine.org/welcome-back-my-friends-to-the-show-that-never-ends-partii-generation-rescue-attacks-14-studies/ [https://perma.cc/K8ZF-RP8A]; Steven Novella, More On Fourteen Studies, SCI.-BASED MED. (Apr. 15, 2009), https://sciencebasedmedicine. org/more-on-fourteen-studies [https://perma.cc/V5X6-R2JK].

120. See Steve Karnowski, Autism Fears, Measles Spike Amount Minn. Somalis, Boston (Apr. 2, 2011), http://archive.boston.com/lifestyle/health/articles/2011/04/02/ autism fears measles spike among minn_somalis/ [https://perma.cc/2KHA-CTKB].

121. Id.; see also Amanda Z. Naprawa, Don't Give Your Kid That Shot!: The Public Health Threat Posed by Anti-Vaccine Speech and Why Such Speech Is Not Guaranteed Full Protection Under the First Amendment, 11 CARdozo Pub. L., PoL'y, \& ETHICs J. 473, 477-78 (2013) (explaining how measles made a comeback in the United States).

122. Liz Szabo, Studies Show Impact of Childhood Vaccinations, USA TODAY, June 9, 2014, at 3A.

123. Pamala Gahr et al., An Outbreak of Measles in an Undervaccinated Community, 134 PEDIATRICS, at e220, e222 (2014), http://pediatrics.aappublications.org/content/early/ 2014/06/03/peds.2013-4260 [https://perma.cc/NUY5-5Y8M]. Numbers were updated due to communication with one of the authors through email. Email from Patricia "Patsy" Stinchfield, Senior Dir., Infection Prevention \& Control, The Skin Integrity Program \& The Children's Immunization Project at Children's Minn., to Dorit R. Reiss, Professor of Law, U.C. Hastings Coll. of the Law (Mar. 30, 2018) (on file with author).

124. Gahr et al., supra note 123, at e225; Email from Patricia "Patsy" Stinchfield to Dorit R. Reiss, supra note 123. 
medical researcher known for his now discredited assertion of a link between MMR vaccine and autism, met with Somali parents of autistic children in Minnesota [three] times since December 2010, and came back to Minnesota during the outbreak on March 23, 2011. ${ }^{125}$

This also suggests that the Department of Health did not realize the extent of the problem in the Somali community until 2011, when the outbreak happened. ${ }^{126}$ Once aware of the problem, the Department started collaborating with the community and intensive work was done. ${ }^{127}$ But at that point, links to anti-vaccine activists had already been established, as described. ${ }^{128}$

In 2017, mostly in Hennepin County, Minnesota, a larger measles outbreak took place. The outbreak started in April, ended in August, ${ }^{129}$ and the number of people affected was higher than all measles cases in the United States in 2016. ${ }^{130}$ There were seventy-five cases in the outbreak. ${ }^{131}$ Sixtyone of them were in young Somali children, twenty-one of those children were hospitalized, one with a second readmission for a total of twentytwo admissions. ${ }^{132}$ None were in intensive care. ${ }^{133}$ The cost to public health

125. Gahr et al., supra note 123, at e225 (citations omitted) (first citing F. DeStefano, Vaccines and Autism: Evidence Does Not Support a Causal Association, 82 ClinIC PhARMACOLOGY \& TheraPeUTICS 756, 756 (2007); then citing Retraction-Ileal-LymphoidNodular Hyperplasia, Non-Specific Colitis, and Pervasive Developmental Disorder in Children, 375 LANCET 445, 445 (2010); then citing Maura Lerner, Anti-Vaccine Doctor Meets with Somalis, STARTRIBUNE (Mar. 24, 2011, 10:46 AM), http://www.startribune.com/ anti-vaccine-doctor-meets-with-somalis/118547569/ [https://perma.cc/U4PR-6GX7]; and then citing Susan Perry, Fear and Frustration Dominated Somali Community Forum on Measles, Vaccines and Autism, MinNPost (Mar. 28, 2011), https://www.minnpost.com/secondopinion/2011/03/fear-and-frustration-dominated-somali-community-forum-measles-vaccinesand-au/ [https://perma.cc/7B49-87LZ]). For a discussion on Andrew Wakefield's misrepresentations about MMR, see Brian Deer, How the Case Against the MMR Vaccine Was Fixed, 342 BMJ 77 (2011), https://www.bmj.com/content/342/bmj.c5347 [https://perma.cc/ LUX3-Z3FT].

126. See Lynn Bahta \& Asli Ashkir, Addressing MMR Vaccine Resistance in Minnesota's Somali Community, 98 MINN. MED. 33, 33 (2015), https://www.mnmed.org/MMA/media/ Minnesota-Medicine-Magazine/Clinical_Bahta_1510.pdf [https://perma.cc/BFF9-TGWX].

127. See id.

128. Id.

129. Lindsey Wahowiak, Minnesota Health Workers Team with Community to End Measles Outbreak, NATION's HeALTH, Nov. 2017, at 13.

130. See Jacqueline Howard, Minnesota Measles Outbreak Exceeds Last Year's Nationwide Numbers, CNN (June 2, 2017, 3:52 PM), https://www.cnn.com/2017/06/02/ health/minnesota-measles-outbreak-bn/index.html [https://perma.cc/EM9U-8HH3].

131. Measles Disease Statistics, MinN. DeP'T HEALTH, http://www.health.state.mn.us/divs/ idepc/diseases/measles/stats.html [https://perma.cc/BT78-8GK3].

132. Annual Summary of Communicable Diseases Reported to the Minnesota Department of Health 2017, supra note 5, at 14; Email from Patricia "Patsy" Stinchfield to Dorit R. Reiss, supra note 123.

133. Hall et al., supra note 1; Email from Patricia "Patsy" Stinchfield to Dorit R. Reiss, supra note 123 . 
was high. ${ }^{134}$ In an email communication with the Minnesota Department of Health, we were told: "The active response period of the outbreak lasted five months at a cost of $\$ 2.3$ million for the combined three entities for which we have cost information. These three entities include the Minnesota Department of Health, Hennepin County, and a metro children's hospital."135

\section{MEASLES, MMR, AND MISREPRESENTATION INVOLVING RISK OF PHYSICAL HARM}

This Section examines whether a plaintiff can apply the tort of misrepresentation in a suit against the anti-vaccine organizations who worked to convince parents in the Somali community in Minnesota that MMR causes autism. The outbreak provides a factual backdrop to examine the tort.

Are advocates against vaccination potentially liable for misrepresentation causing physical damage to those relying on such misrepresentations and others foreseeably injured? Clearly, case law is very protective of publishers and presumably other similar mass media presentations addressing public issues and concerns. ${ }^{136}$ At the same time, publishers are still subject to defamation law targeting individuals, corporations, and small groups. ${ }^{137}$ Similarly, manufacturers of tobacco and medicine products may be liable for causing physical injury. ${ }^{138}$ Furthermore, case law indicates this liability extends, in certain cases, to defendants merely associated with the manufacturers as trade organizations or when a brand manufacturer's misrepresentation injures the users of generic version of its products. ${ }^{139}$ It is also well established that physicians and other health providers are liable to their patients and

134. Julia Belluz, Why Minnesota Lost a Battle Against Anti-Vaccine Campaigners, Vox (May 16, 2017, 11:18 AM), https://www.vox.com/science-and-health/2017/5/10/15591410/ minnesota-measles-anti-vaccine-public-health-lessons [https://perma.cc/U9NV-9SZD] (Kristen Ehresmann of the Department of Health referring to the 2017 outbreak: "We did some projections about the cost of this measles outbreak and calculated the cost for the first [twenty-one] days - $\$ 207,000$ - and that was just for the Minnesota Department of Health, not for county health departments, all the health care facilities that had to ramp up staffing. It doesn't include direct medical costs that have been incurred. We're in week five, and if the outbreak lasts three months, it'll be close to $\$ 900,000$ - so just under a million for the State Health Department alone.").

135. E-mail from Cynthia Kenyon to Dorit R. Reiss, supra note 6.

136. See supra text accompanying notes $46-51$.

137. See supra text accompanying notes 52-53.

138. See supra text accompanying notes $43-44$.

139. See supra text accompanying notes 30-33, 44 . 
foreseeable third parties for physical injuries proximately caused by their negligent misrepresentations. ${ }^{140}$ This liability encompasses the failure to recommend appropriate medicine, including vaccines.

Between these two poles of books and manufacturers on one side and physicians and other health service expert relationships on the other, where do advocates against vaccinations fall? The more they approach quasi-book and other mass media advocates debating in the public arena, the stronger their protection from negligent misrepresentation. ${ }^{141}$ The more they approach personal, or at least small group expert health counsellors or specific expert advisors serving specific families, the more liability appears quite possible, assuming objective falsity and negligence are established. This liability should be applicable even when individual or limited group counseling is supplemented by media presentation endorsed by the counsellors. By this analysis, the degree of relationship and dependency can matter as well as the assertion of expert or professional competence. Put another way, the closer one's behavior is to instruction or incitement rather than just description or espousing an ideology, the less protected one is when speaking to a group.

This is not to suggest that litigation will actually happen. In 1997, the Supreme Court of Minnesota declined to recognize the tort of negligent misrepresentation involving risk of physical harm. ${ }^{142}$ This would be an obstacle to those seeking to use the tort in Minnesota, though not an insurmountable one - the court can reconsider, and the events surrounding the 2017 outbreak may be a good opportunity to do so. But even if it does not, there are two reasons to use this case study anyway. First, the varying methods used by anti-vaccine organizations to influence this community offer a factual montage to analyze when tort liability could or should be applied. Second, this is not the only example of anti-vaccine activists targeting an individual or a community and considering the extent or limit of liability can help assess when imposing liability is or is not appropriate.

In this thought exercise, two interconnected organizations and one individual in particular can be singled out as potential defendants. The Vaccine Safety Council of Minnesota (the Council) openly and clearly acknowledged that it had a role in influencing the Somali community. ${ }^{143}$ In a statement from May 9, 2017, the Council acknowledged its participation, while alleging

140. See supra text accompanying notes 38-42.

141. Although they still are not protected from defamation or trade disparagement liability, which are beyond the scope of this Article.

142. Smith v. Brutger Cos., 569 N.W.2d 408, 414 (Minn. 1997).

143. Statement from the Vaccine Safety Council of Minnesota, AGE AuTISM (May 9, 2017, 12:04 PM), http://www.ageofautism.com/2017/05/urgent-statement-from-the-vaccinesafety-council-of-minnesota.html [https://perma.cc/9AMG-9YC5] [hereinafter Statement from the Council]. 
invitation by community members who "invited us to speak [] in their community to their neighbors and friends about their rights under the law in the state of Minnesota." "144 The Council organized several presentations by anti-vaccine activists, including Andrew Wakefield in 2011 and other activists during the 2017 outbreak, aiming to convince the community of their views. ${ }^{145}$ Connected to that, the anti-vaccine blog Age of Autism published numerous articles by its own members and members of the Council. For example, local Minnesota anti-vaccine activist Nancy Hokkanen, who is also a contributor editor to the blog, published an article emphasizing the link to MMR . ${ }^{146}$ The Council's statement was published on the Age of Autism's blog. ${ }^{147}$ J.B. Handley also published the letter on the Age of Autism blog calling on community members not to give MMR. ${ }^{148} \mathrm{He}$ is a regular writer for and closely associated with that blog. ${ }^{149} \mathrm{Mr}$. Handley, as was mentioned, also funded the trip of members to the conference Autism One, where activists provided further presentations claiming MMR causes autism. ${ }^{150}$

This Section examines whether there is a viable suit against the Council, Age of Autism, and J.B. Handley under Section 311, starting with the duty question. There are two parts to this question. First, did the activists have a duty to members of the community who, in reliance on their claims, did not vaccinate their children with MMR if those children contracted measles. Second, is there a duty to third parties - other members of the community, or even members outside the community - who contracted measles from a child left unvaccinated because of the misrepresentations. In part, this latter issue is also covered in the discussion of reliance.

As a starting point for the discussion of duty to the community members, there is at least an arguable claim in some specified contexts that the relationship between the anti-vaccine activists and the individuals in the community in question created a legal duty. The Council clearly and explicitly targeted the community in an effort to convince members of their viewpoint. ${ }^{151}$ Council members spoke to individuals in the community in addition to

144. Id.

145. See Sun, supra note 2.

146. See Hokkanen, supra note 106

147. Statement from the Council, supra note 143.

148. J.B. Handley, Point of View: Mandatory Vaccines Are Bad Medicine, Bad Politics, Age Autism (Dec. 11, 2018, 6:00 AM), https://www.jbhandley.com/autism.html [https:// perma.cc/WN9J-DZM7].

149. Id.

150. See Khalif, supra note 110.

151. See Statement from the Council, supra note 143. 
organizing group events. ${ }^{152}$ Arguably, people attending events put on by the Council, and potentially, people getting information from those attending those events, can argue a more specific duty than the general public can. On the other hand, the line between a community member attending an event aimed at the entire community and a member of the public seeing something on TV - where duty is generally absent ${ }^{153}$ - is less than clear; in both cases, the message is not individualized. Would we find a duty only for small communities? What about a local TV station, broadcasting for a community in a defined geographic area?

We believe that in this case, the organization's representations targeted specific individuals in the group, individually and in small groups, which the organization actively worked to court and establish relationships with. This active targeting created a duty of care towards those individuals when they relied on the information the organization provided. The organization's actions could demonstrate an intent to create a specific relationship with individuals, even when those contacts were in small group settings. These actions were closer to a consultant offering counsel than to a TV station broadcasting to the general public. This was not a general message to the public in the hope that some members would be receptive; it was a clear and pointed campaign to get vulnerable individuals to act in a certain way.

Most clearly, negligent representations specifically made to an individual, even when supplemented by coordinated group and media presentations, can constitute counseling behavior justifying liability for physical harm. The organization purports to be providing expert knowledge and advice with the intent to cause reliance on their advice regarding vaccination. There is also certainly a strong argument that counseling in a small group context without specific individual interactions should lead to liability. The analogy to group counseling is still compelling. Should a presentation to a large lecture group, clearly intended to incite actions without specific interaction, be sufficient to impose liability? While less clear, there is precedent that speakers in groups can be held criminally liable as accessories if their words are not merely reflecting ideas but spoken with the intent to incite, though within careful limits. ${ }^{154}$ As noted in the Diamond and

152. See id.

153. See Bailey v. Huggins Diagnostic \& Rehab. Ctr., Inc., 952 P.2d 768, 772 (Colo. App. 1997).

154. See Leslie Kendrick, Free Speech and Guilty Minds, 114 CoLum. L. REV. 1255, 1269 (2014) (citing Brandenburg v. Ohio, 395 U.S. 444, 447 (1969) (per curiam)); see also Planned Parenthood of the Colum./Willamette, Inc. v. Am. Coal. of Life Activists, $41 \mathrm{~F}$. Supp. 2d 1130, 1155 (D. Or. 1999), aff'd in part, vacated and remanded in part, $290 \mathrm{~F} .3 \mathrm{~d}$ 1058 (9th Cir. 2002). The holding was affirmed by the Ninth Circuit. Planned Parenthood of the Colum./Willamette, Inc. v. Am. Coal. of Life Activist, 290 F.3d 1058, 1088 (9th Cir. 2002). 
Primm typology, there is little reason to protect group instructional harm while holding accountable less extensive individual counseling. ${ }^{155}$ The factual issue is whether instruction and counseling were intended to impact identifiable individuals and not simply espouse ideology.

The other two potential defendants raise harder questions. Mr. Handley published his letter addressing the community on a blog. This is akin to making a general representation - as in Bailey v. Huggins Diagnostic \& Rehabilitation Center, Inc., where a dentist directed his representations at the public, and the court there found no duty of care. ${ }^{156}$ However, Mr. Handley's letter was more targeted than the dentist's communications, and clearly intended to create action on the part of the community. ${ }^{157}$ In the letter, Mr. Handley mentioned direct phone and email communications with the Somali parents he is writing to, suggesting a much closer connection than between the Bailey plaintiff and dentist speaking on TV. ${ }^{158}$ In his own words, Mr. Handley wants to "offer this advice" to the group in question. ${ }^{159}$ Again, this suggests a closer link than a viewer of a TV show; perhaps the Bailey court would have ruled differently if the dentist mailed VHS recordings of his broadcast to the plaintiff. Mr. Handley also flew members of the community to Autism One. ${ }^{160}$ While that was not a direct misrepresentation by him, it is, again, evidence of a relationship and actions that can be seen to create a duty of care. ${ }^{161}$ Generally, one who acts has a duty of care to foreseeable plaintiffs for foreseeable harms arising from his or her action. ${ }^{162}$

The natural, foreseeable result of convincing people not to vaccinate is an outbreak of the disease they were not vaccinated against. Mr. Handley appears to have cultivated a special relationship with the community through personal communications and interactions aimed at giving the community a specific message. His later article followed and reinforced that message. There is a strong argument that Mr. Handley owed a duty of care to those individuals who received personal telephone and email communications in conjunction with other more general communications. It is, however, questionable whether community members only reading a letter posted on

155. See Diamond \& Primm, supra note 56, at 973.

156. Bailey, 952 P.2d at 772-73.

157. See Handley, supra note 107.

158. Id.

159. Id.

160. See Khalif, supra note 110.

161. See id.

162. See, e.g., Palsgraf v. Long Island R.R. Co., 162 N.E. 99, 101 (N.Y. 1928). 
a blog would have a sufficient nexus to successfully bring a claim of negligent misrepresentation under current case law. At the same time, as noted above and elaborated on in the following sections, there are policy arguments to impose liability on general communications in blogs and books specifically intending to provide instructions and incite action. ${ }^{163}$

The most challenging case to apply Section 311 to is Age of Autism. The blog hosted numerous articles directed at the Somali community, including Mr. Handley's letter and the Council's statement. But the blog is akin to a TV station or a publisher, where most courts do not find duty. ${ }^{164}$ The argument against the blog Age of Autism would have to draw on the fact that some of the articles directly targeted the community. The argument would be that this was not a publication to the public at large but to a specific group of people. While Age of Autism does have a more general following, what they did in relation to the Somali community is more specific. They repeatedly published articles questioning MMR in that community alleging a link between the vaccine and autism. These articles worked to create a mistrust of the Health Department and a belief of that link. The argument here would be that the repeated articles place the blog closer to an advocate that sends messages to a specific person or identified group in an effort to get it to act than to a general online publication. Perhaps this is analogous to cases where courts have found duty when former employers wrote letters of recommendations without knowing of a specific employer but knowing of a group that could be made vulnerable by the communication. ${ }^{165}$

The case for imposing liability on the blog is much weaker than it is for the Council-which organized events and brought speakers and met with community members — or Handley's direct solicitations. It also raises issues with quantification: How large does a target audience need to be for it to be the target of a general publisher? Every publisher of information wants to reach a certain audience that is more or less well-defined. In this case, again, arguably the audience was reasonably well-defined - but it was not an extremely small group.

We think it is important to remember here, however, that the well-defined group was an extremely vulnerable one. First, immigration is stressful. It is even more so when, as here, the reason for immigrating was a crisis in

163. See Diamond \& Primm, supra note 56, at 970-71.

164. See Bailey v. Huggins Diagnostic \& Rehab. Ctr., Inc., 952 P.2d 768, 772 (Colo. 1997); see also infra note 243 and accompanying text.

165. See, e.g., United States v. Buttorff, 572 F.2d 619, 623, 628 (8th Cir. 1978) (upholding criminal convictions for aiding and abetting the filing of false or fraudulent income tax forms based on defendants addresses at large public gatherings); Randi W. v. Muroc Joint Unified Sch. Dist., 929 P.2d 582, 584 (Cal. 1997). 
the home country. ${ }^{166}$ Second, the cultural stigma attached to autism, the news coverage of the study showing higher rates within their community, and communication problems with the health department all left this particular group, as described in Part III, extremely vulnerable. ${ }^{167}$ The anti-vaccine groups fed into this uncertainty, stressing that the department of health was not trustworthy. ${ }^{168}$ In other words, the Somali community was vulnerable to this specific type of misrepresentation, and the antivaccine activists targeting them knew of that vulnerability. Nevertheless, despite such susceptibility, current case law would most likely view a blog akin to a book and provide the author with immunity from misrepresentation liability. First Amendment protections for book-like activities, including arguably blogs, appear entrenched within our jurisprudence. ${ }^{169}$ This is despite the fact that books and other publications are regularly subject to libel. ${ }^{170}$ This poses the question of whether future case law development, still solicitous of First Amendment values, might also impose liability for more broadly communicated instructional misrepresentations.

\section{A. Liability to Third Parties}

The courts, for a long time, have recognized a duty to a third party infected with a disease as a result of a doctor's negligence to a patient. ${ }^{171}$ A similar duty was found in the context of a residential health facility. ${ }^{172}$ At least some courts recognized that a person infected with HIV owes a duty of care not just to those he or she had intercourse with, but to family

166. See Carola Suárez-Orozco \& Marcelo M. Suárez-Orozco, Children of IMMIGRATION 69-71 (2001).

167. See Scuglik et al., supra note 104, at 587.

168. Handley, supra note 107. "[Y] ou cannot trust the Minnesota Department of Health to do the right thing." Id.; see also Carroll, supra note 109.

169. See Bailey, 952 P.2d 768; see also infra note 243 and accompanying text.

170. See Gertz v. Robert Welch, Inc., 418 U.S. 323, 332-33, 340 (1974) (allowing liability with fault for matters of public concern).

171. See Davis v. Rodman, 227 S.W. 612, 613 (Ark. 1921); Hofmann v. Blackmon, 241 So. 2d 752, 752 (Fla. Dist. Ct. App. 1970); Shepard v. Redford Cmty. Hosp., 390 N.W.2d 239, 241-42 (Mich. Ct. App. 1986); Skillings v. Allen, 173 N.W. 663, 664 (Minn. 1919); McIntosh v. Milano, 403 A.2d 500, 509 (N.J. Super. Ct. Law Div. 1979); Jones v. Stanko, 160 N.E. 456, 458 (Ohio 1928); DiMarco v. Lynch Homes-Chester Cty., Inc., 583 A.2d 422, 424-25 (Pa. 1990). But see Molien v. Kaiser Found. Hosps., 616 P.2d 813, 814-15 (Cal. 1980) (imposing liability because the physician told a woman infected with syphilis to inform her husband, suggesting that there may be a liability risk either way).

172. See Bolieu v. Sisters of Providence in Wash., 953 P.2d 1233, 1246 (Alaska 1998). 
members of that person. ${ }^{173}$ Related, a physician who did not give a patient proper advice to avoid spreading hepatitis to a third party had a duty to the infected third party. ${ }^{174}$ In contrast, a court found no duty on the part of family members of a person infected with HIV when representations they made to his fiancée that his disease was chronic Lyme and heavy metal poisoning led her to delay treatment against HIV. ${ }^{175}$ The court there found that while there is a duty on the part of the person engaging in a sexual relationship to disclose his disease, extending it to family members is going too far. ${ }^{176}$

This jurisprudence suggests that there is no general duty to disclose an infectious disease, but there may be a duty where there is a special duty from elsewhere or where the circumstances support finding one.

In this case, the strongest argument for imposing a duty owed to third parties is the nature of the misrepresentations. The natural result of an effort to convince a group not to vaccinate is to put group members at risk of infectious disease and creating a risk to others. Part of the reason for imposing a duty on a doctor to a third party in the infectious disease context is that the patient is expected to rely on the doctor's recommendation. The most natural result of negligence in this context is expecting a person who is not vaccinated to infect others. While the path here is different, the predictable outcome of not preventing an infectious disease is a risk not just to the person infected but to those he or she can infect. Limiting duty to exclude third parties means that the person misrepresenting would not internalize anywhere near the full consequences of his or her action.

Nevertheless, the jurisprudence seems hesitant to extend duty for misrepresentation-especially when it is directed to a group rather than an individual — and extending it to a third party may be too cumbersome. That said, the infectious diseases context is different than others, because of the nature of these diseases.

\section{B. Other Elements of Misrepresentation}

The First Amendment also would be Age of Autism's strongest defense. Neither the Council nor Handley acted as publishers or a media forum, where First Amendment concerns dismiss most cases. ${ }^{177}$ Nonetheless, the question of whether there should be protection from the First Amendment is relevant. Vaccines are a public health measure, which almost by definition

173. See Mussivand v. David, 544 N.E.2d 265, 273 (Ohio 1989).

174. DiMarco, 583 A.2d at 425.

175. Doe v. Dilling, 888 N.E.2d 24, 44-45 (Ill. 2008).

176. Id.

177. See, e.g., Smith v. Linn, 563 A.2d 123, 127 (Pa. Super. Ct. 1989), aff'd, 587 A.2d 309 (Pa. 1991). 
makes them a matter of public concern. There is value in a robust, open discussion on vaccine safety and effectiveness because it can help provide oversight and push policy makers to work harder to assure safety. Arguably, there is room to allow even some incorrect statements if they promote the public debate and can promote scrutiny.

However, there are also reasons to allow tort liability. False statements about vaccines can lead to direct harm: A false statement that a vaccine is safe, when it is not, can harm people. ${ }^{178}$ False statements attributing vaccines to risks they do not have - that they cause autism — can lead to an outbreak with direct costs in harms and death. This has recently been the case in Europe, where several people, almost all unvaccinated, have died from measles since the beginning of 2017 in an outbreak linked to non-vaccinating. ${ }^{179}$ Misleading people into not vaccinating can directly result in harms and deaths, and those may well not be limited to the people misled: They can infect others. The Minnesota outbreak went beyond the community. In another outbreak in San Diego, California, an unvaccinated boy contracted measles in Switzerland and when he came back infected others in his pediatrician's office and his school, including infants too young to vaccinate. ${ }^{180}$ Further, when groups put substantial effort into convincing people-especially members of a vulnerable population - to reject the health department's recommendations and not vaccinate, at some point they are going beyond just presenting information, correct or not, online. In Diamond and Primm's typology, at some point this behavior approaches giving direction on use - or non-use - of a product. ${ }^{181}$ There is no clear justification to treat these speakers different than, say, tobacco trade associations promoting information about cigarettes - or even manufacturers giving instructions on how to use products. $^{182}$ Their claims that being unvaccinated is not dangerous are analogous to researchers who suggested lead exposure was not dangerous ${ }^{183}$

178. See Donald C. Arthur, Negative Portrayal of Vaccines by Commercial Websites: Tortious Misrepresentation, 11 U. MASs. L. REV. 122, 160-64 (2016).

179. Eur. CTR. FOR Disease PREVENTION \& CONTROL, MONTHLy MEASLES AND Rubella MONITORING REPORT 2 (2018), https://ecdc.europa.eu/sites/portal/files/documents/MonthlyMeasles-Rubella-monitoring-report-June-2018.pdf [https://perma.cc/A2UV-5DPG].

180. David E. Sugerman et al., Measles Outbreak in a Highly Vaccinated Population, San Diego, 2008: Role of the Intentionally Undervaccinated, 125 PEDIATRICS 747, 74748 (2010).

181. See Diamond \& Primm, supra note 56, at 996-97.

182. See generally Guidry v. U.S. Tobacco Co., 188 F.3d 619 (5th Cir. 1999).

183. See White v. Kennedy Krieger Inst., Inc., 110 A.3d 724, 733-34 (Md. Ct. Spec. App. 2015). 
or officials making negligent and harmful weather predictions. ${ }^{184}$ The situations are different, but the reality of culpably providing false information -negligently or intentionally - that can put others at risk is similar. The case law clearly does not support absolute protection against misrepresentation.

$$
\text { C. Falsity }
$$

Is the information false, and were the speakers negligent towards its falsity? The specific and relevant piece of information that the anti-vaccine organizations promoted is that MMR causes autism. The short answer is that there is overwhelming evidence that there is no link between MMR and autism, and the alleged evidence supporting a link is deeply flawed. Multiple studies from across the world examined this question. In 1999, a British team looked at whether there was a link between autism and MMR, studying children born as far back as $1979 .{ }^{185}$ They found a steady increase in diagnoses but with no jump after the introduction of MMR, no difference between those vaccinated and those not, no difference in when autism was diagnosed, and no clusters of changes after MMR. ${ }^{186}$ In 2001, another British team looked at all children aged twelve or younger in 1988-1999 in the UK and found that while rates of MMR uptake remained constant at $95 \%$ throughout the time, rates of autism rose continuously. ${ }^{187}$ There was no correlation between MMR uptake and autism rates. ${ }^{188}$ Canadian autism researchers Eric Fombonne and Suniti Chakrabarti examined ninety-six children with autism compared to a pre-MMR cohort and another post-MMR cohort, and no evidence was found of a link to MMR. ${ }^{189}$ Three Finnish scholars studied 535,544 children to see if there is a link between MMR and autism, and found none. ${ }^{190}$ In 2003, a review of twelve studies also found no link. ${ }^{191}$ A Canadian study looking at 27,749 children found that while prevalence was increasing, the increase was at

184. Connelly v. State, 84 Cal. Rptr. 257, 258 (Ct. App. 1970).

185. Brent Taylor et al., Autism and Measles, Mumps, and Rubella Vaccine: No Epidemiological Evidence for a Causal Association, 353 LANCET 2026, 2026 (1999).

186. Id.

187. James A. Kaye, Maria del Mar Melero-Montes \& Hershel Jick, Mumps, Measles, and Rubella Vaccine and the Incidence of Autism Recorded by General Practitioners: A Time Trend Analysis, 322 BMJ 460, 460-61 (2001).

188. Id. at 460.

189. Eric Fombonne \& Suniti Chakrabarti, No Evidence for a New Variant of MeaslesMumps-Rubella-Induced Autism, 108 PeDiATRICS E58, E58 (2001).

190. Annamari Mäkelä, J. Pekka Nuorti \& Heikki Peltola, Neurologic Disorders After Measles-Mumps-Rubella Vaccination, 110 Pediatrics 957, 957 (2002).

191. Kumanan Wilson et al., Association of Autistic Spectrum Disorder and the Measles, Mumps, and Rubella Vaccine: A Systematic Review of Current Epidemiological Evidence, 157 ArChives Pediatrics Adolescent Med. 628, 628 (2003). 
the same rate before and after the introduction of MMR, and further, the increase in autism diagnoses continued when rates of MMR vaccination decreased. ${ }^{192}$ Most recently, a study of 95,727 children in the United States examined whether MMR increases the risk of autism in children generally and siblings of children with autism - a high-risk group - and found no link. ${ }^{193}$ Other studies also found no link. ${ }^{194}$

Why do the groups who reached out to the Somali community believe otherwise? In part, it is due to a charismatic and seemingly legitimate figure-Andrew Wakefield; in part, due to a search for answers by distressed parents; and in part, due to a belief in a grand conspiracy to hide vaccine harms. None of these can withstand scrutiny.

While claims of MMR causing autism slightly predated it, the earliest apparently-scientific support for the claim that vaccines cause autism was a case study consisting of twelve children, eight of which had autism, by British gastroenterologist Andrew Wakefield. ${ }^{195}$ He suggested a new syndrome under which MMR caused both gastrointestinal problems and autism. ${ }^{196}$ Although the paper itself did not state MMR causes autism, Wakefield made that claim in a press conference regarding the paper, repeated the claims again during a media interview, and even testified at a United States Congressional hearing. ${ }^{197}$ But starting in 2004, startling revelations came out about the paper and Wakefield. ${ }^{198}$ An investigative journalist, Brian Deer, discovered that Wakefield had received large payments - more than $\$ 100,000$ - to serve as an expert witness in planned litigation against MMR manufacturers, and that five out of the eight children with autism

192. Eric Fombonne et al., Pervasive Developmental Disorders in Montreal, Quebec, Canada: Prevalence and Links with Immunizations, 118 PEDIATRICS, at e139, e139-40 (2006).

193. Anjali Jain et al., Autism Occurrence by MMR Vaccine Status Among US Children with Older Siblings with and Without Autism, 313 JAMA 1534, 1534 (2015).

194. See, e.g., G. Baird et al., Measles Vaccination and Antibody Response in Autism Spectrum Disorders, 93 ARCHIVES Disease ChILD 832, 832 (2008); Mady Hornig et al., Lack of Association Between Measles Virus Vaccine and Autism with Enteropathy: A Case-Control Study, 3 PLoS ONE, at e3140, e3140 (2008); Liam Smeeth et al., MMR Vaccination and Pervasive Developmental Disorders: A Case-Control Study, 364 LANCET 963, 963 (2004).

195. Paul A. Offit, Autism's False Prophets: Bad Science, Risky Medicine, AND THE SEARCH FOR A CURE 18-24 (2008).

196. Id. For the retracted study, see Andrew J. Wakefield et al., RETRACTED: IlealLymphoid-Nodular Hyperplasia, Non-Specific Colitis, and Pervasive Developmental Disorder in Children, 351 LANCET 637 (1998).

197. OFFIT, supra note 195, at 20, 30.

198. See id. at 37-46. 
were among the plaintiffs in that litigation - a fact not disclosed to either Wakefield's co-authors or the journal editor. ${ }^{199}$ Further, Wakefield had apparently misrepresented the timelines of the children's symptoms and their bowel-related symptoms, for example, omitting constipation. ${ }^{200}$ Further, at the same time as he made claims about MMR - claims he should have known were problematic-Wakefield had filed for his own patent for a single measles vaccine. ${ }^{201}$ Following these revelations, Wakefield was disgraced. In 2010 he was found guilty of serious ethical violations by the British General Medical Council, struck off the medical register-lost his license to practice medicine - and his article was retracted. ${ }^{202}$ Wakefield still believes and repeatedly claims MMR causes autism. ${ }^{203}$ Despite the discovery of Wakefield's misrepresentations and his disgrace, a small group of believers still stand behind him - and these include the members of the Vaccine Safety Council of Minnesota, the Age of Autism blog, and J.B. Handley.

The Vaccine Safety Council of Minnesota brought Wakefield in to talk to the Somali community three times, knowing of his belief in the link between MMR and autism. ${ }^{204}$ The Age of Autism blog has repeatedly published articles in support of him. ${ }^{205}$ J.B. Handley stated in an interview with the New York Times from 2011: "To our community, Andrew Wakefield is Nelson Mandela and Jesus Christ rolled up into one .... He's a symbol of how all of us feel." 206

These are strong indications that Wakefield's words are an important influence on the activists making representations to the Somali community. But the words of someone shown to have misrepresented data in his initial study, misled in other ways by hiding conflicts of interests, and found guilty

199. Id. at 37-41.

200. Brian Deer, How the Case Against MMR Was Fixed, 342 BMJ 77, 78-81 (2011).

201. Id. at 81.

202. OFFIT, supra note 3, at 136-137.

203. Id. at $140-45$.

204. See Gahr et al., supra note 123, at e225 (first citing Lerner, supra note 125; and then citing Perry supra note 125).

205. See, e.g., Anne Dachel, Dr. Andrew Wakefield Continues to Speak Out, AGE AuTISM (July 16, 2014, 5:45 AM), http://www.ageofautism.com/2014/07/dr-andrew-wakefieldcontinues-to-speak-out.html [https://perma.cc/PMK2-ZLKC]; John Stone, The Global Vaccine Crisis of 2018: Why Andrew Wakefield Is Back in the News, AGE AuTISM (July 24, 2018, 1:02 AM), http://www.ageofautism.com/2018/07/the-global-vaccine-crisis-of2018-why-andrew-wakefield-is-back-in-the-news.html [https://perma.cc/KZQ7-GGP4]; John Stone, The Lies About Andrew Wakefield, AGE AUTISM (Mar. 26, 2016, 5:54 AM), http://www.ageofautism.com/2016/03/the-lies-about-andrew-wakefield.html [https://perma.cc/ 95AC-4NP4].

206. Susan Dominus, The Crash and Burn of an Autism Guru, N.Y. TiMES (Apr. 20, 2011), https://www.nytimes.com/2011/04/24/magazine/mag-24Autism-t.html [https://perma.cc/ K4PR-6QFD]. 
of serious ethical violations by a disciplinary body are not a good counter to multiple large-scale studies by different teams in different countries. Wakefield's continued assertions that MMR causes autism does not change the overwhelming evidence to the contrary and relying on him as a source on this issue, given his past misrepresentations, is unreasonable.

Another source for the belief that MMR causes autism are parents who have noticed, or recall having noticed, children exhibit symptoms right after the MMR vaccine. ${ }^{207}$ This can be the result of one of three things: parents noticing the symptoms around the period of the vaccine even though the child was exhibiting symptoms of autism before that date, a child suffering regressive autism right after the vaccine, or the parents misremembering. ${ }^{208}$ Autism Spectrum Disorder (ASD) is a disorder that involves communication and social issues, and parents may not notice the symptoms until the age where children are expected to start communicating and socializing more. ${ }^{209}$ The Centers for Disease Control and Prevention (CDC) points out that:

\begin{abstract}
Some children with an ASD seem to develop normally until around [eighteen] to [twenty-four] months of age and then they stop gaining new skills, or they lose the skills they once had. Studies have shown that one third to half of parents of children with an ASD noticed a problem before their child's first birthday, and nearly $80 \%-90 \%$ saw problems by [twenty-four] months of age. ${ }^{210}$
\end{abstract}

Note that a majority of parents do not notice a problem before one year. $^{211}$ The first dose of MMR is recommended in the range between twelve to eighteen months old. ${ }^{212}$ With around four million children in a

207. For a story by one Somali parent describing these observations, see generally Abdulkadir Khalif, Measles, Minneapolis and Somali Kids, AGE AuTISM (Mar. 28, 2011, 5:45 AM), http://www.ageofautism.com/2011/03/measles-minneapolis-and-somali-kids.html [https://perma.cc/L8JS-2ZD4].

208. On misremembering, see generally Sally Ozonoff et al., Reliability of Parent Recall of ASD Symptom Onset and Timing, 22 AUTISM 891 (2018). Note that identifying onset of symptoms of autism can be very challenging. See Sally Ozonoff et al., Onset Patterns in Autism: Variation Across Informants, Methods, and Timing, 11 AUTISM RES. 788, 788-89 (2018).

209. Signs and Symptoms of Autism Spectrum Disorders, CENTERS FOR DISEASE CONTROL \& PREVENTION (last updated Apr. 26, 3018), https://www.cdc.gov/ncbddd/autism/signs.html [https://perma.cc/C487-HFPG].

210. Id.

211. See id.

212. U.S. Dep't of Health \& Human Servs., Ctrs. for Disease Control \& Prevention, MMR (Measles, Mumps, and Rubella) Vaccine: What You Need to KNOw 1 (2018), https://www.cdc.gov/vaccines/hcp/vis/vis-statements/mmr.pdf [https://perma.cc/ MQ65-4LN9]. 
birth cohort, ${ }^{213}$ it is to be expected that some parents will notice symptoms around that age - whether because they did not notice those symptoms before or because the child regressed and lost skills. By coincidence alone, some of these can occur after MMR. And parents may misremember or misattribute. Two examples can demonstrate that. The case of a child called Michelle Cedillo - a child with ASD, who also suffered severe, deep disabilities - was examined by a federal adjudicative program designed to examine claims of harms from vaccines. ${ }^{214}$ Michelle's mother testified that she was a happy baby with "normal" habits until she received her MMR vaccine at the age of sixteen months. ${ }^{215}$ But the Special Master examining her case - in a detailed decision rejecting the claim that vaccines caused her autism-quoted two experts who reviewed Michelle's baby videos and pointed to symptoms of autism from when Michelle was an infant. ${ }^{216}$ The symptoms manifested before the mother noticed them, and before the receipt of MMR - but the family still believed she only became autistic after MMR. $^{217}$

In another case, Dr. Brian Hooker also testified that the first symptoms of his son's ASD manifested after the MMR he received together with a few other vaccines. ${ }^{218}$ But the child had symptoms of developmental delay as early as four months of age, long before that vaccine. ${ }^{219}$ And there was no indication of a dramatic change in the medical records around the receipt of MMR. ${ }^{220}$

The potential for a coincidental temporal association between MMR and ASD when there is no causal link is why studies examining MMR rates and autism in large groups of people are important. Those studies, as discussed above, have been done - and they found no link between MMR and autism. ${ }^{221}$ The organizations in question are well aware of the studies, but reject them, drawing on these personal anecdotes or on other claims.

213. Joyce A. Martin et al., Births: Final Data for 2015, 66 NAT'L VitAl StAT. ReP. 1, 1 (2017), https://www.cdc.gov/nchs/data/nvsr/nvsr66/nvsr66_01.pdf [https://perma.cc/ 352G-QMSK].

214. Cedillo v. Sec'y of HHS, No. 98-916V, 2009 WL 331968, at*5-6, *9 (Fed. Cl.

Feb. 12, 2009), aff'd 617 F.3d 1328 (Fed. Cir. 2010).

215. Id. at *4-6.

216. Id. at *95-96.

217. Id. at $* 100$.

218. Hooker v. Sec'y of HHS, No. 02-472V, 2016 WL 3456435, at *1, *6 (Fed. Cl. May 19, 2016).

219. Id. at *9.

220. Id. at $* 10$.

221. For a review of some of the studies, see Luke E. Taylor, Amy L. Swerdfeger \& Guy D. Eslick, Vaccines Are Not Associated with Autism: An Evidence-Based Meta-Analysis of Case-Control and Cohort Studies, 32 VACCINE 3623, 3625 (2014). 
Repeated large scale studies show that MMR is not linked to autism. ${ }^{222}$ Claiming otherwise based on a small number of personal anecdotes is both false and unreasonable.

Finally, the organizations believed that there was a conspiracy to hide evidence that vaccines cause autism. ${ }^{223}$ For example, Mark Blaxill, editor of Age of Autism, who the Vaccine Safety Council of Minnesota brought to talk to Somali parents in the middle of the 2017 outbreak, and who, among other things, suggested that MMR caused autism, drew on a conspiracy theory prevalent in anti-vaccine groups. ${ }^{224}$ This theory centered on a relatively small 2004 study of MMR and the child's age at the time of the vaccine's administration. ${ }^{225}$ The conspiracy theory centers on an actual CDC scientist who claimed that his co-authors refused to include a sub-result showing a statistically significant association between MMR and autism in AfricanAmerican children in the final study. ${ }^{226}$ The association went away when the scientists controlled for confounders suggesting that it was spurious. ${ }^{227}$

222. See id. at 3625-27.

223. See Mark Blaxill, Mark Blaxill: My Hanging Offense, AGE AuTiSm (Sept. 5, 2017, 6:00 AM), http://www.ageofautism.com/2017/09/mark-blaxill-my-hanging-offense.html [https://perma.cc/9ANL-WTAG].

224. See id.

225. Matt Carey, A Look Back at the So Called "CDC Whistleblower" Story and How Vaxxed is Misleading, LEFT BRAIN RIGHT BRAIN (Feb. 10, 2017), https://leftbrainright brain.co.uk/2017/02/10/a-look-back-at-the-so-called-cdc-whistleblower-story-and-howvaxxed-is-misleading/ [https://perma.cc/FA5R-JNDP].

226. See id.

227. See CDC Statement Regarding 2004 Pediatrics Article, “Age at First MeaslesMumps- Rubella Vaccination in Children with Autism and School-Matched Control Subjects: A Population-Based Study in Metropolitan Atlanta," CENTERS FOR DiseASE CONTROL \& PREVENTION (Dec. 7, 2015), https:/www.cdc.gov/vaccinesafety/Concerns/Autism/cdc2004 pediatrics.html [https://perma.cc/J6BA-TDGG].

Access to the information on the birth certificates allowed researchers to assess more complete information on race as well as other important characteristics, including possible risk factors for autism such as the child's birth weight, mother's age, and education. This information was not available for the children without birth certificates; hence CDC study did not present data by race on black, white, or other race children from the whole study sample. It presented the results on black and white/other race children from the group with birth certificates.

Id.; see also, David Gorski, Vaccine Whistleblower: An Antivaccine "Exposé" Full of Sound and Fury, Signifying Nothing, SCI.-BASED MED. (Aug. 24, 2015), https://sciencebased medicine.org/vaccine-whistleblower-an-antivaccine-expose-full-of-sound-and-fury-signifyingnothing/ [https://perma.cc/9PFS-QNJC]. For a discussion on confounders, see Andrea C. Skelly, Joseph R. Dettori \& Erika D. Brodt, Spectrum Research, Inc., Assessing Bias: The Importance of Considering Confounding, 3 EVIDENCE BASED SPINE CARE J. 9, 9 (2012). 
Confounders are variables that influence the measured variables, potentially confusing causation: For example, if you are examining whether a child's place in the family order is related to Down's Syndrome without controlling for maternal age, you could end with an incorrect picture because maternal age influences the risk of Down's Syndrome and increases with the order in the family. ${ }^{228}$ That the MMR and autism result is spurious is supported by the many studies that found no link between MMR and autism in anyone, the fact that rates of autism are not substantially higher among AfricanAmerican children than Caucasians, ${ }^{229}$ and the lack of biological basis for such a difference. In a letter signed by multiple physicians, the point was made that:

\footnotetext{
Recently, members of the African[-]American community have become concerned that certain vaccines may not be safe for their children or that they may cause autism. This is simply not true. The worldwide scientific community has conducted multiple studies and reviews demonstrating that neither vaccines, nor components of vaccines, are linked to autism. Many of these published scientific studies are listed below.

....

Furthermore, African[-]American children are no more likely to develop autism than White, Asian or Hispanic children. ${ }^{230}$
}

There is no good evidence that the CDC conspired to hide a link between vaccines and autism, or that there is a link between MMR and autism. Even if the 2004 study found an actual link, and it did not, it would be contradicted by many larger studies. It is unreasonable to focus on a conspiracy claim based on a small study and ignore the extensive data from all around the world - data the CDC could not control, since the studies were not done under its jurisdiction. Yet that is exactly what Blaxill said, speaking at an event organized by the Vaccine Safety Council of Minnesota to make exactly those claims, said. ${ }^{231}$

Similarly, anti-vaccine sites that analyzed studies emphasize conflicts of interests, some very strange. For example, one such site considered funding

228. See Wayne W. LaMorte, What is Confounding?, B.U. Sch. Pub. Health (2016), http://sphweb.bumc.bu.edu/otlt/MPH-Modules/BS/BS704-EP713 Confounding-EM/BS704EP713_Confounding-EM2.html\# [https://perma.cc/UZ3U-B43A]; Charles R. Stark \& Nathan Mantel, Nat'l Cancer Inst., Effects of Maternal Age and Birth Order on the Risk of Mongolism and Leukemia, 37 J. NAT'L CANCER INST. 687, 688, 692 (1966).

229. Carey, supra note 225.

230. Errol Alden, et Al., Immunize, The Safety of Vaccines for African AMERICAN CHILDREN, https://web.archive.org/web/20171001071156/http://www.ecbt.org/ images/articles/Vaccine_Safety_and_African_American_Children.pdf [https://perma.cc/ LG4V-Z58Q]; see also Carey, supra note 225; Autism Spectrum Disorder (ASD), NAT'L Inst. Mental HeAlth (Apr. 2018), https://www.nimh.nih.gov/health/statistics/autism-spectrumdisorder-asd.shtml [https://perma.cc/4ZK7-6PRQ].

231. Blaxill, supra note 223. 
from the department of health to be a problem. ${ }^{232}$ For one study of MMR, the conflict of interests statement that led the anti-vaccine organization to dismiss it was: "This study was supported by a grant from the Canadian Institutes for Health Research, Ottawa, Ontario. Dr Wilson is a Canadian Institutes for Health Research New Investigator."233 Funding by government health departments is not a conflict of interest, unless you assume a conspiracy to hide information by government. That appears to be the assumption here, but there is no support for it. The site does not actually show flaws in the studies. ${ }^{234}$ The data shows that the claim that MMR causes autism is false, and there is no reasonable basis to believe otherwise.

\section{Reliance}

The last element of the tort is reliance. For the parents directly in communication with the anti-vaccine organization, the question is whether it was reasonable to rely on people who, after all, are not professionals and are counseling against listening to professionals. There is a good argument that the reliance here was reasonable. Because of problems in communication, the group lost trust in the health department. The anti-vaccine groups came in backed by Wakefield, referred to routinely by them as "Doctor" Wakefield, a man with real medical credentials. They fed into the fears of parents of children with autism in a new country - a vulnerable population. Relying on their claims was not unreasonable, especially given the previously mentioned vulnerability of the community. While those falling sick are the children of the parents relying on such misrepresentation, that is not a barrier; parents make medical decisions for children, absent a reason for state intervention, and misrepresentation to parents about childhood vaccines directly implicates the children. ${ }^{235}$

Note that in a thoughtful article from 2009, Alissa Strong recommended limiting Section 311 to professionals or people holding themselves out as experts. ${ }^{236}$ Strong offers the argument that the purpose of Section 311 "is to ensure that those who possess expertise - those upon whom non-experts are therefore entitled to rely-conduct themselves in a reasonable way and

\footnotetext{
232. FOURTEEN STUD., supra note 119.

233. Id.

234. For a discussion of the Fourteen Studies site, see Novella, supra note 119.

235. This is similar to the situation in White v. Kennedy Krieger Inst., Inc., 110 A.3d 724, 747-49 (Md. Ct. Spec. App. 2015).

236. See Strong, supra note 12, at 140.
} 
do not recklessly advise others to take perilous courses of action. ${ }^{.237}$ Strong is also clearly concerned about employment cases in which employers writing letters of recommendations were held liable for future misconduct of the employee; because of the effect of such cases, employers may no longer write letters and information about candidates is curtailed. ${ }^{238}$ While we understand Strong's concerns, we disagree that the tort was designed to solely apply to experts. In fact, we think that the Restatement (Second) formulation, by expressly removing the requirements of a professional context, rejected that interpretation. ${ }^{239}$ Even under that requirement, the organizations here in their presentations and letters clearly held themselves out as experts. ${ }^{240}$ However, we think narrowing the restatement in such a way simply does not fit its text or the jurisprudence interpreting Section 311. While sympathetic to Strong's concern about chilling effects, we believe that there is also a cost in overly narrowing the tort.

The reliance here would spread to those who heard the misrepresentations from neighbors and friends. However, while this goes further, the antivaccine organizations were aiming to reach the entire community. Their events were opened to all community members. Mr. Handley's letter was addressed to "the Somali Parents of Minnesota"-not just to the people who participated in previous events or that he met, but to all the parents in the community. ${ }^{241}$ In these circumstances, limiting the liability to those that directly heard the information from the anti-vaccine groups seems to offer the presenters more defense than they merit. Similarly, in the context of infectious diseases, third party harm comes up. Previous cases have limited tort liability to third parties for infectious diseases to specific contexts, like between doctors and patients. But arguably, anti-vaccine misrepresentation leads precisely to a risk of outbreak. An outbreak, by its nature, can put third parties at risk, because infectious diseases do not stay limited to one person. We therefore posit that Section 311 should include third party reliance.

Further, there are compelling reasons to extend the reliance both to friends and neighbors and to third parties infected by children sickened in direct reliance on the misrepresentations. The courts' hesitation to allow third party reliance appears to be a concern about extensive liability disproportionate to the culpability of the negligent actor. ${ }^{242}$ These are especially strong when the group relying is ill defined. For example, a dentist's statements on TV

237. Id. at 147-48 (citing W. Page Keeton et Al., Prosser and Keeton on the LAW OF TORTS $\S 107$, at 745 (5th ed. 1984)).

238. Id. at $120-26$.

239. See id. at 116-18, 143.

240. Id. at 114

241. Handley, supra note 107.

242. See Bailey v. Huggins Diagnostic \& Rehab. Ctr., Inc., 952 P.2d 768, 772 (Colo. App. 1997). 
may reach an untold number of plaintiffs, and many others. ${ }^{243}$ In contrast, even though an employer's letter of recommendation can affect an unidentified number of people - for example, if an employee sexually harasses multiple students in another school - cases were allowed. ${ }^{244}$ While the main reason was that the final plaintiff was likely not to rely on the misrepresentations, the fact that the affected group is relatively well-defined and not the entire public is relevant. ${ }^{245}$

This case is likely closer to the employment recommendation case in that we have a reasonably well-defined group of plaintiffs - people who have relied on repetitions by neighbors about the disease, and people infected by those who relied on the misrepresentation. In the employment case, the Court stated:
Under the Restatement provisions, plaintiff need only allege that her injury resulted from action that the recipient of defendants' misrepresentations took in reliance on them. In a case involving false or fraudulent letters of recommendation sent to prospective employers regarding a potentially dangerous employee, it would be unusual for the person ultimately injured by the employee actually to "rely" on such letters, much less even be aware of them. ${ }^{246}$

Here, too, the third parties were infected because their parents, the initial listeners, did not vaccinate their children with MMR. It can be argued that their injury is a direct result of the actions their parents - the recipients of the misrepresentations - took in direct reliance of the anti-vaccine activists' representations. It was reasonably foreseeable such misrepresentations would harm not only the children of the parents the activists made the representations towards, but also those they may infect. As to the level of culpability, while anti-vaccine activists sincerely believe that vaccines are bad, they are keenly aware that their views are not accepted by the medical community. ${ }^{247}$ They are also keenly aware that not vaccinating is connected to outbreaks, and often react defensively. ${ }^{248}$ A common reaction is to understate

243. See id.

244. See Randi W. v. Muroc Joint Unified Sch. Dist., 929 P.2d 582, 586 (Cal. 1997).

245. Id. at 594

246. Id.

247. See, e.g., Cathy Jameson, Things to Know or Do When You're Up Against a Vaccine Bully, AGE AUTISM (Oct. 20, 2013, 5:45 AM), http://www.ageofautism.com/2013/10/thingsto-know-or-do-when-youre-up-against-a-vaccine-bully.html [https://perma.cc/BGS2-3AFG] (addressing "vaccine bullies," including doctors - most doctors - who want parents to vaccinate).

248. Anne Dachel, Deliberate Ignorance: Minnesota Measles'Spotty Reporting IS Contagious, AGE AuTiSm (May 8, 2017, 6:00 AM), http://www.ageofautism.com/2017/05/ 
the risks of diseases like measles, but doing so also highlights that they know the link between non-vaccinating and the infection, and are aware that the broader community sees their actions as dangerous. ${ }^{249}$ The activists are not making an inadvertent mistake; they are consciously choosing to reject expert opinion - and global expert opinion, at that, having been told of the risks of their actions. That is a higher level of culpability than mistakes in weather prediction, and potentially even than writing a letter of recommendation omitting suspicions of sexual harassment. This, too, supports liability.

\section{GOING BROAD: LIABILITY FOR HARMS FROM NON-VACCINATING}

This Section will address two issues. First, why focus on Section 311, rather than Section 310, conscious misrepresentations that cause bodily harm? $?^{250}$ Second, what are the boundaries of the tort? When should it lead to liability in the context of anti-vaccine misinformation, and when should it not? We hope our insights in this can offer guidance in other contexts, too, but think there is a value to addressing a well-defined issue, not just because of its own importance but because it allows comparisons and allows lines to be drawn more meaningfully by limiting the subject matter.

We have decided to focus the Article on Section 311 because we believe that showing the intent needed for Section 310 would be very difficult and likely impossible. Our focus is on the knowledge requirement. Section 310 requires that the actor:

(b) knows
(i) that the statement is false, or
(ii) that he has not the knowledge which he professes. ${ }^{251}$

deliberate-ignorance-minnesota-measles-spotty-reporting-is-contagious.html [https://perma.cc/ 9DXB-PU2G].

249. See Mark F. Blaxill, Measles Hysteria -The Truth About a Non-Epidemic in Eight Simple Slides, AGE AutiSM (Feb. 24, 2015, 5:45 AM), http://www.ageofautism.com/2015/ 02/measles-hysteria-the-truth-about-a-non-epidemic-in-eight-simple-slides.html [https://perma.cc/ MY4Y-Z3SP].

250. Section 310 of Restatement (Second) of Torts states:

An actor who makes a misrepresentation is subject to liability to another for physical harm which results from an act done by the other or a third person in reliance upon the truth of the representation, if the actor

(a) intends his statement to induce or should realize that it is likely to induce action by the other, or a third person, which involves an unreasonable risk of physical harm to the other, and

(b) knows

(i) that the statement is false, or

(ii) that he has not the knowledge which he professes.

RESTATEMENT (SECOND) OF TORTS $\S 310$ (AM. LAW INST. 1965).

251. Id. 
There are strong grounds to suspect that the anti-vaccine activists who went into the Somali community sincerely believe that MMR causes autism. First, they have consistently made claims suggesting that vaccines cause autism, and as the discussion above shows, have solidly stood behind Wakefield in his disgrace. In an article about his visit to the Somali community, anti-vaccine activist Blaxill, an editor of the blog Age of Autism referred to above, described parents' choice not to give MMR to their children because of concerns about autism as "a rational response from informed parents to an urgent childhood health problem."252

This latest comment also addresses the other prong of the requirement. If the activists believe, as it suggests, that they are informed - and many articles suggest that they make an effort to read the studies and remain informed, even if they do not have the training to understand them and read them with clear bias - they do not know that they do not have the knowledge they profess. ${ }^{253}$ They are likely negligent in rejecting the extensive evidence against them, as described, but that is not enough for Section 310.

\section{A. How Far Can Misrepresentation Go?}

Another question is whether, and to what extent, can Section 311 be applied to different situations. One, where incorrect information originating from an anti-vaccine organization or person led to a child being left unvaccinated and suffering harm. Two, where an unvaccinated child infects another with a preventable disease causing that person harm. There are different scenarios in which this could happen. Parents can be misled when an anti-vaccine organization post materials online, ${ }^{254}$ or an anti-vaccine

252. Blaxill, supra note 223.

253. See J.B. Handley, Did Chinese Scientists Find Autism's Missing Puzzle Piece?, Age Autism (Mar. 27, 2018, 6:00 AM), http://www.ageofautism.com/2018/03/did-chinesescientists-find-autisms-missing-puzzle-piece.html [https://perma.cc/QLG6-7PWW]; Dan Olmsted, MMR and the Simple Truth About Autism, AGE AUTISM (Feb. 7, 2008, 6:00 AM), http://www.ageofautism.com/2008/02/mmr-and-the-sim.html [https://perma.cc/FNL5-32YX]; Del Bigtree High Wire Features Blaxill, Handley, Kennedy and Hooker, AGE AUTISM (July 13, 2018, 6:00 AM), http://www.ageofautism.com/2018/07/del-bigtree-high-wirefeatures-blaxill-handley-kennedy-and-hooker.html [https://perma.cc/AQ2W-2EUK].

254. See NAT'L VAccine InFo. CTR., VACCINATION. Your Health. YOUR FAMILY. Your CHOICE. (2016), https://www.nvic.org/CMSTemplates/NVIC/pdf/49-Doses-PosterB.pdf [https://perma.cc/J6AH-593W]. 
activist creates a misleading video ${ }^{255}$ or an anti-vaccine organization creates a billboard with frightening and false information about vaccines. ${ }^{256}$ That is not, however, the only situation in which anti-vaccine activists provide information. One anti-vaccine activist has approached and addressed people in parks to convince them to stop vaccinating. ${ }^{257}$ Another mentioned the many conversations she has with parents, sometimes when they reach out, sometimes initiated by her. ${ }^{258}$ A large anti-vaccine organization posted proudly that "[i]n 2018 alone . . 6,500 [p]eople [r]eceived [o]ne-on-[o]ne [s] upport [f]rom [National Vaccine Information Center] counselors." 259 There is also no reason to assume that anti-vaccine activists will not target other communities the same way they targeted the Somali community in Minnesota. In fact, we have seen exactly such targeting towards the Jewish Orthodox community in New York. ${ }^{260}$

Duty is weakest, and the First Amendment is strongest, where the information is posted in a public forum for general consumption. Courts

255. See Dr. Suzanne Humphries, Dr. Suzanne at Caljam 2017. Vaccination: Manipulating a Mystery, YouTUBE (Apr. 11, 2018), https://www.youtube.com/watch?v=acTJZG6xe7I [https://perma.cc/HYX2-SB3J].

256. See New Learn the Risk Billboard in Philadelphia ... . LEARN THE RISK (Mar. 26, 2018), https://www.learntherisk.org/news/new-learn-the-risk-billboard-in-philadelphia/ [https://perma.cc/X2L5-8PT8].

257. Facebook Interview with Forrest Maready (Mar. 7, 2018, 12:05 PM), https:// www.facebook.com/brittneykara/videos/vb.1481829303/10215183262403191/?type=2\& theater [https://perma.cc/TAX2-M5GB].

258. See Cathy Jameson, Asking Questions About Vaccines and Autism, Age Autism (Apr. 9, 2017, 6:00 AM), http://www.ageofautism.com/2017/04/asking-questions-aboutvaccines-and-autism.html [https://perma.cc/7FWZ-UU75]; Cathy Jameson, Baby of Mine, Age Autism (Aug. 30, 2015, 5:45 AM), http://www.ageofautism.com/2015/08/baby-ofmine.html [https://perma.cc/RAB7-D2ZF]; Cathy Jameson, Overheard, AGE AuTISM (Jan. 21, 2018, 6:00 AM), http://www.ageofautism.com/2018/01/overheard.html [https://perma.cc/ R5YX-EQLN].

259. Nat'l Vaccine Info. Ctr., In 2018 Alone ..., FACEBOOK (Nov. 20, 2018), https:// www.facebook.com/national.vaccine.information.center/photos/p.10156536381317931/1 0156536381317931/?type=1\&theater [https://perma.cc/MWJ9-7T8V]. The National Vaccine Information Center (NVIC) is one of the largest anti-vaccine organizations in the United States. See About National Vaccine Information Center, NAT'L VACCINE INFO. CTR., http:// www.nvic.org/about.aspx [https://perma.cc/JF7S-DH98]; see also PAUL A. OfFIT, DEADLY CHOices: How the ANTI-VACCINE MOVEMENT ThreATENs Us All 57-77 (2011) (explaining how NVIC individuals, such as Barbara Loe Fisher, used media outlets to voice their opinions on vaccinations to nationwide audiences). On its legislative efforts, see, for example, Denise F. Lillvis, Anna Kirkland \& Anna Frick, Power and Persuasion in the Vaccine Debates: An Analysis of Political Efforts and Outcomes in the United States, 1998-2012, 92 MILBANK Q. 475, 477, 503 (2014).

260. Lena H. Sun \& Ben Guarino, Anti-Vaxxers Target Communities Battling Measles, WASH. Post (May 20, 2019), https://www.washingtonpost.com/national/health-science/ antivaxxers-go-viral-in-communities-battling-measles/2019/05/20/a476417c-78d7-11e9bd25-c989555e7766_story.html?utm_term=.410e6c0a1c0b [https://perma.cc/V73T-M9UB]. 
consistently reject application of Section 311 to publishers ${ }^{261}$ and the media. ${ }^{262}$ While the organizations here are not publishers publishing third parties' work, but publish content they themselves create, the broad audience still makes the duty argument very hard: the potential duty would be extremely broad, applying to anyone who could be affected. Further, public pronouncements on matters of public concern-like public health-are likely where the First Amendment is strongest. ${ }^{263}$

One potential counter is that the publishers' jurisprudence is not applicable here, exactly because the content is created by the anti-vaccine organizations publishing it. They are the authors, not the publisher. While that is a difference, and the jurisprudence on this emphasized the burden on publishers required to check on authors' work, ${ }^{264}$ the other cases-the media cases - do not have the same distinction, as often the forum is also the originator of at least part of the content, for example, employees state the content or the forum chooses guests. ${ }^{265}$ It is a possible distinction, but our view of the totality of the cases is that at the heart of this jurisprudence is the desire to allow more, not less, scope for public discussion of matters of public concern, and this applies here too.

Another potential argument is that clearly incorrect speech on factual issues is less protected than other forms of speech. ${ }^{266}$ This argument has support in the literature: factually incorrect and harmful speech has less protection than other forms of speech, especially commercial false speech, but also to some extent non-commercial speech. ${ }^{267}$ Several existing regulatory schemes directly target harmful false speech, allowing federal agencies to take action against unfair business practices that affect commerce ${ }^{268}$ or

261. See, e.g., Alm v. Van Nostrand Reinhold Co., 480 N.E.2d 1263, 1266 (Ill. App. Ct. 1985); Smith v. Linn, 563 A.2d 123, 126 (Pa. Super. Ct. 1989), aff'd, 587 A.2d 309 (Pa. 1991).

262. Bailey v. Huggins Diagnostic \& Rehab. Ctr., Inc., 952 P.2d 768, 772 (Colo. App. 1997); see also Diamond \& Primm, supra note 56, at 969-70, 973.

263. See Snyder v. Phelps, 562 U.S. 443, 444-48 (2011).

264. See Smith, 563 A.2d at 125-26.

265. See Bailey, 952 P.2d at 772.

266. See Naprawa, supra note 121, at 501-02; see also Arthur, supra note 178, at $187-88$.

267. Martin H. Redish \& Kyle Voils, False Commercial Speech and the First Amendment: Understanding the Implications of the Equivalency Principle, 25 WM. \& MARY BILL RTS. J. 765, 767-68 (2017).

268. See 15 U.S.C. $\S 45$ (2012). 
harmful claims about medical products. ${ }^{269}$ All states have parallels to the Federal Trade Commission Act, allowing state agencies to act to protect consumers against misleading claims. ${ }^{270}$ While the First Amendment sets limits on what can be done against misleading speech, those are not absolute. ${ }^{271}$ The First Amendment does not completely prevent suits for defamation or intentional infliction of emotional distress, though it sets limits on them. ${ }^{272}$ Anti-vaccine sites vary between those who blatantly warn against vaccines ${ }^{273}$ and those which present themselves as providing neutral information without making direct recommendations. ${ }^{274}$ This puts anti-vaccine sites on a continuum between Diamond and Primm's directions and instructions category - where there is a strong argument that liability is appropriate even for general media outlets - and that of just describing information without recommendations. ${ }^{275}$ Many anti-vaccine sites carry a warning that they are not recommending vaccinating or not vaccinating, even though their information is clearly designed to make vaccines appear in a negative light. ${ }^{276}$ There is a strong case that for those sites, the jurisprudence prevents lawsuits, even if the information in them is misleading, under the reasoning that chilling speech should have strong reasons behind it, and that consumers bear some responsibility in sorting out good from bad sources.

While there is also a reasonable argument for allowing such suits to go forward-because there is a good argument that there is little value to misleading information that can put the receiver of the information and the community at risk - there are real concerns about allowing them. For example, misrepresentation suits can be brought against anyone putting information online, and when the standard is negligence, it can lead to potentially long, costly litigation that can chill provision of accurate information as well. To give one example, small pro-vaccine nonprofits

269. See Autism: Beware of Potentially Dangerous Therapies and Products, FDA (last updated Nov. 9, 2017), https://www.fda.gov/ForConsumers/ConsumerUpdates/ucm 394757.htm [https://perma.cc/B8N9-R3NZ].

270. See Kathleen S. Morris, Expanding Local Enforcement of State and Federal Consumer Protection Laws, 40 FordHAM URB. L.J. 1903 app. at 1928-49 (2013).

271. See, e.g., Nat'l Inst. of Family \& Life Advocates v. Becerra, 138 S. Ct. 2361, 2365-67 (2018).

272. See Snyder v. Phelps, 562 U.S. 443, 461-63 (2011) (Breyer, J., concurring); Walter V. Schaefer, Defamation and the First Amendment: The Coen Lecture, 52 U. ColO. L. REV. 1, 7-8 (1980).

273. See Vaccines, LEARN THE RISK (2018), https://www.learntherisk.org/vaccines/ [https://perma.cc/XSS2-3WMJ].

274. See About National Vaccine Information Center, supra note 259. For a discussion of more examples of such websites, see Arthur, supra note 178, at 165-69.

275. See Diamond \& Primm, supra note 56, at 989-91.

276. See About National Vaccine Information Center, supra note 259; see also Anna Kata, A Postmodern Pandora Box: Anti-Vaccination Misinformation on the Internet, 28 VACCINE 1709, 1712-14 (2010). 
could also be sued under claims that some of their online information is inaccurate - and even if they could prove the case in court, costly litigation is hard and challenging for small nonprofits, whether or not they are right. Some protection of organizations for online information protects small nonprofits and allows more information from more sources to be available. While there is a risk and a cost-people can be harmed by incorrect information online - we think that the value of having more information from more sources supports limiting negligent misrepresentation suits for online materials.

Another potential argument is that like other rights, the First Amendment is not absolute, and when the risk from misinformation is direct harm to persons relying on the information and - in the case of infectious diseases - to others, there is more cause to restrict the speech. ${ }^{277}$ One Article, criticizing Smith v. Lynn, described this as a tension between life and the First Amendment, and suggested life should win more often. ${ }^{278}$ This argument has been raised in, and rejected by, the media cases that examined misrepresentation. ${ }^{279}$ The reasoning is that there is no way to balance the risk to the individual and the public without courts making judgments about the content of the speech that they may not be well-placed to make. ${ }^{280}$ There is value in having a robust discussion in the public sphere about matters of public concern.

However, that concern is weaker when there is a targeted communicationan effort to influence a specific group - or closer connections, for example, efforts to influence a person. Participants in a class providing false antivaccine claims, for example, or a mother or father directly targeted, may have a claim under Section 311.

Another problem in such cases is that falsity will not always be as clear cut as in the case of the claim that MMR causes autism. Some claims will be, but others will not. For example, one common tactic by the anti-vaccine organization the National Vaccine Information Center is to provide the number of reports received by the Vaccine Adverse Event Reporting System (VAERS) as evidence that a vaccine causes harm. To give a few examples,

277. Arthur, supra note 178, at 160-61, 164.

278. See Heather Appleton, Note, The First Amendment: Is the Freedom of Speech More Important than the Protection of Human Life?, 12 LOY. L.A. ENT. L.J. 585, 609-14 (1992).

279. See Diamond \& Primm, supra note 56, at 970, 973.

280. See id. at 993-94. 
they did that for meningococcal vaccines, ${ }^{281}$ for Hib vaccines, ${ }^{282}$ and for HPV vaccines, ${ }^{283}$ among others. While not false - the information correctly reflects the number of reports - this information is highly misleading: VAERS is a passive reporting system into which anyone can report anything, true or not, caused by vaccines or not, and without investigation, a causal link to vaccines cannot be assumed. ${ }^{284}$ This is not mentioned, and the reports are provided and left-which could easily lead people not familiar with the system to assume these are, in fact, caused by the vaccines. Similarly, the National Vaccine Information Center says, truthfully, that drug companies did not test the safety or effectiveness of influenza or Tdap vaccines in pregnancy and that the FDA categorizes them as category $\mathrm{B}$ and $\mathrm{C}$, which means that adequate testing has not been done in humans to demonstrate safety for pregnant women, even though they are recommended in pregnancy. ${ }^{285}$ It omits, however, the fact that researchers outside the

281. See Meningococcal Disease \& Vaccine, NAT'L VACCINE InFo. CTR., https:// www.nvic.org/Vaccines-and-Diseases/Meningitis.aspx [https://perma.cc/HY39-BNS4] ("Using the MedAlerts search engine, as of August 31, 2018 . . . the federal Vaccine Adverse Events Reporting System (VAERS), which includes only a small fraction of the health problems that occur after vaccination in the U.S., had recorded more than 3,544 serious health problems, hospitalizations and injuries following meningococcal shots, including 171 deaths with about $55 \%$... of the serious adverse events occurring in children under age six.").

282. See Can Hib Vaccine Cause Injury?, NAT'L VACCINE INFO. CTR., https://www. nvic.org/vaccines-and-diseases/hib/hib-vaccine-injury.aspx [https://perma.cc/T88Y-YNJ8] ("According to MedAlerts.org (a searchable VAERS database) as of October 31, 2017, there have been more than 37,416 reports of hib vaccine reactions, hospitalizations, injuries and deaths following hib vaccinations made to the federal Vaccine Adverse Events Reporting System (VAERS), including 2,540 related deaths, 14,223 hospitalizations, and 1,445 related disabilities. Over $93 \%$ of those serious HIB vaccine-related adverse events occurred in children three years old and under. Of these hib-vaccine related deaths reported to VAERS, $13 \%$ of the deaths occurred in children under three years of age. Of these reported deaths, 1,955 occurred in infants under the age of 6 months. Serious reactions included deaths and such things as anaphylactic reaction, asthma, pneumonia, convulsions, noninfectious encephalitis, acute pancreatitis, peripheral neuropathy, Guillain-Barre syndrome, sepsis, seizures, and cerebral edema.").

283. See Human Papillomavirus (HPV) Disease and Vaccine Information, NAT'L VACCINE INFO. CTR., https://www.nvic.org/Vaccines-and-Diseases/hpv.aspx [https://perma.cc/ UD9D-39RD] ("Using the MedAlerts search engine, as of April 30, 2018, the federal Vaccine Adverse Events Reporting System (VAERS) contains more than 58,992 . . reports of HPV vaccine reactions, hospitalizations, injuries and deaths [following HPV vaccinations] and, includes 430 related deaths, 794 hospitalizations, and 2,773 disabling conditions. Over $45[\%]$ of the serious adverse events occurred in children and teens [twelve to seventeen] years of age.").

284. See Guide to Interpreting VAERS Data, VACCINE ADVERSE EVENT REPORTING SYS., https://vaers.hhs.gov/data/dataguide.html [https://perma.cc/9VMQ-R7VK].

285. See Barbara Loe Fisher, Vaccination During Pregnancy: Is it Safe?, NAT'L VACCINE INFO. CTR. (Nov. 9, 2013, 9:48 AM), https://www.nvic.org/NVIC-VaccineNews/November-2013/Vaccination-During-Pregnancy-Is-It-Safe-.aspx [https://perma.cc/ 6HZG-4RCA]. 
companies have conducted many studies on the safety of both Tdap ${ }^{286}$ and influenza ${ }^{287}$ in pregnancy, and the studies show both to have excellent safety records.

When information is framed as questions - "ask these questions before vaccinating"-it is even harder to show misrepresentation, even if the questions are designed to create fear and doubt. ${ }^{288}$

A final question is how reasonable reliance on an anti-vaccine organization or individual is. Here, social norms matter. It is usual for parents to ask advice from other parents. Relying on a parent who seems knowledgeable is common. However, there is a good argument that preferring the views of another parent over that of a medical professional is not reasonable. This should be a case by case analysis, looking at the vulnerability of the parent asking for help, the apparent authority and source of knowledge of the parent giving the information, and the other sources of information.

For an organization, legitimacy probably depends on the characteristics of the organization. If it has professionals, or people who appear as experts, if it has a website that looks professional, or if it appears to provide both risks and benefits, an organization may easily appear legitimate to people not familiar with it. For example, the National Vaccine Information Center presents its information as referenced and researched, ${ }^{289}$ and - truthfully - presents its president as the author of several books about vaccines and a member of federal committees. ${ }^{290}$ This can lend the organization an air of legitimacy. The Vaccine Safety Council of Minnesota presents itself as an "advocacy team of parents, health professionals and educators," again suggesting a legitimate organization with experts. ${ }^{291}$ Naturally, each organization will try to present as legitimate a front as possible. Under these circumstances, reasonable people may see the organization as a legitimate

286. See Pregnancy and Whooping Cough, CENTERS FOR Disease CONTROL \& PREVENTION (last updated June 29, 2017), https://www.cdc.gov/pertussis/pregnant/research.html [https://perma.cc/G5MX-AAEL].

287. See Flu Vaccine and Pregnancy Research, CEnTERS FOR Disease CONTROL \& PREVENTION (last updated Aug. 10, 2017), https://www.cdc.gov/vaccines/pregnancy/hcptoolkit/flu-vaccine-pregnancy-research.html [https://perma.cc/S9FZ-VRLN].

288. See, e.g., Examining NVIC's "If You Vaccinate, Ask 8," NVIC HoNESTY (Oct. 31, 2014, 3:38 AM), https://nvichonestly.wordpress.com/2014/10/31/examining-nvics-ifyou-vaccinate-ask-8/ [https://perma.cc/5VMW-4JK8].

289. About National Vaccine Information Center, supra note 259.

290. Biography, Barbara Loe Fisher, NAT'L VACCINE INFO. CTR., https://www.nvic.org/ about/barbaraloefisher.aspx [https://perma.cc/MT8T-T55D].

291. About VSCM, VACCINE SAFETY COUNCIL MINN., http://vaccinesafetycouncil minnesota.org/about/ [https://perma.cc/UQ4K-YHZT]. 
source of information, and reasonably rely on the information it provides. There may be a difference here between more or less sophisticated, more or less vulnerable plaintiffs. But in cases of doubt, there is probably a social argument for protecting reliance on a legitimate-seeming organization. In terms of cost allocation, if an organization makes an effort to appear legitimate and invite reliance, it is likely fair to place the costs of harms from such reliance on it, rather than on the relying individual. The reliance is exactly what the organization was trying to create.

\section{CONCLUSION}

While, because of the importance of free debate, there is room for caution when approaching a tort based on speech, especially on matters of public concern in our community, we have traditionally compensated for misrepresentation. A situation where a vulnerable population is intentionally targeted with misinformation that can sicken, even kill its members and others, and where such harm actually materializes, seems to call for compensation. If the tort of misrepresentation as interpreted by the courts cannot afford compensation, there may be errors in the interpretation. 